Article

\title{
Investigation of the Pigments and Glassy Matrix of Painted Enamelled Qing Dynasty Chinese Porcelains by Noninvasive On-Site Raman Microspectrometry
}

\author{
Philippe Colomban ${ }^{1, *(\mathbb{D}}$, Burcu Kırmızı ${ }^{1,2}{ }^{\mathbb{D}}$, Bing Zhao ${ }^{3}$, Jean-Baptiste Clais ${ }^{4}$, Yong Yang ${ }^{5}$ and \\ Vincent Droguet ${ }^{6}$ \\ 1 MONARIS UMR8233, Sorbonne Université, CNRS, 4 Place Jussieu, 75005 Paris, France; kirmizi@yildiz.edu.tr \\ 2 Department of Conservation and Restoration of Cultural Property, Faculty of Architecture, Yıldız Technical \\ University, Yıldız Yerleşkesi B Blok, Beşiktaş, 34349 İstanbul, Turkey \\ 3 CRCAO UMR8155, CNRS, Collège de France, 75005 Paris, France; bing.zhao@college-de-france.fr \\ 4 Département des Objets d'art, Musée du Louvre, quai François Mitterrand, 75001 Paris, France; \\ jean-baptiste.clais@louvre.fr \\ 5 Department of Fine Arts, Palace Museum, Beijing 100009, China; yangyong@dpm.org.cn \\ 6 Chateau-Musée de Fontainebleau, Place Charles de Gaulle, 77300 Fontainebleau, France; \\ Vincent.droguet@culture.gouv.fr \\ * Correspondence: philippe.colomban@sorbonne-universite.fr or philippe.colomban@upmc.fr
}

Received: 24 July 2020; Accepted: 14 August 2020; Published: 17 August 2020

\begin{abstract}
A selection of 15 Chinese painted enameled porcelains from the 18th century (Qing dynasty) was analyzed on-site by mobile Raman and XRF microspectroscopy. The highly prized artifacts are present in the collections of the Musée du Louvre in Paris and Musée Chinois at Fontainebleau Castle in France. In the painted enamels, pigments such as Naples yellow lead pyrochlore, hematite, manganese oxide and carbon and opacifiers such as lead arsenates were detected. The glassy matrices of the enamels mainly belonged to lead-rich and lead-alkali glass types according to the Raman spectra obtained. The glaze and body phases of the porcelain artifacts were also analyzed. The detection of lead arsenate apatite in some of the blue enamels was significant, indicating the use of arsenic-rich European cobalt ores (smalt) and possibly mixing with Asian cobalt. This characteristic phase has also been identified in French soft-paste porcelains and glass decor and high-quality Limoges enamels from the same period. Based on the shape of the Raman scattering background, the presence of colloidal gold $\left(\mathrm{Au}^{\circ}\right.$ nanoparticles) was identified in red, orange and pink enamels. Different types of Naples yellow pigments were also detected with Sb-rich, Sn-rich and mixed Sb-Sn-(Zn, Fe?) compositions in the yellow enamels. The results were compared to previous data obtained on Chinese cloisonné and painted enameled metalware and Limoges enamels as well as French enameled watches.
\end{abstract}

Keywords: porcelain; enamels; China; 18th century; Raman microspectroscopy; pXRF; pigments; arsenic; cobalt; Naples yellow

\section{Introduction}

Technological aspects of ceramic production in the past were not only affected by the mastery and innovation of the local craftsmen but the transfer of technology coming out of cultural interactions between societies. This is well-reflected in the choice of the raw materials used and the firing conditions as well as in decorative processes such as enameling. Regarding porcelain production in the Far East, a long-distance technological transfer is known to have been conducted by Portuguese Jesuit missions in Japan at the beginning of the 17th century [1-3]. Historical records of the Chinese court and Jesuit mission [4-8] also both demonstrated the importation of European enamels and ingredients as well as 
the venue of European craftsmen who had expertise in enameling techniques at the Qing court at the end of 17th century. These enamels are called "falangcai" (琅彩 from falang, a homonym of the "French" character in Chinese) and/or "yangcai", (洋彩 "foreign colors") [9], which are deposited generally over the glaze, the latter being fired beforehand with the porcelain body. Although porcelain production was first achieved in China historically, the craft of enameling is generally suggested to have benefited with Western contacts as early as the 14th century via the Silk Road [10-15].

Scientific analyses of various Chinese [10-15] and European [11,16-18] enameled artifacts have previously confirmed the use of a blue enamel precursor (usually called "smalt") based on European cobalt ores and Naples yellow lead pyrochlore pigments typical of European recipes in enameled metalware and porcelains produced during the Qing dynasty. Furthermore, the use of the European "Cassius purple" method to prepare pink to purple porcelain enamels (the so-called Famille rose) with colloidal gold had been well-established for decades [19]. Due to the rareness of artifacts produced at the Beijing Imperial Palace Workshop (falangzuo (珐琅作), enamel workshop) and, consequently, the lack of fragments of such artifacts, most of the studies have been conducted with noninvasive techniques, in particular on-site with Raman and X-ray fluorescence (XRF) mobile instruments [10-14,16-18,20], which are well-suited for the in situ study of outstanding objects in their secure locations [20-24]. UTF8gbsn We present here an on-site noninvasive Raman study of Chinese porcelain masterpieces assigned to have been produced at the beginning of the 18th century (Yongzheng (1723-1735) and beginning of Qianlong (1735-1796) reigns) belonging to the collections of the Louvre Museum and Chinese Museum at Fontainebleau Castle in France. One artifact has also been analyzed with a mobile XRF microspectrometer. A comparative approach was carried out with the first Raman study focused on porcelains produced at the end of the Kangxi reign (1661-1722) and the beginning of the Yongzheng reign [12] and with painted enameled metalware of the same collections [14] as well as other types of European enameled artifacts [11,16-18].

\section{Methods and Artifacts}

\subsection{Artifacts}

The porcelains analyzed are listed in Table 1 and shown in Figures 1-5. They belong to the collections of the Musée du Louvre (Department of Fine Art Objects) in Paris and Musée Chinois at Fontainebleau Castle, which is located close to Paris. Artifacts from the Fontainebleau Chinese Museum were part of the collection of Napoléon III (1808-1873, president of the French Republic from 1848 to 1852 and then emperor up to 1870) and the Empress Eugénie (1826-1920), while some of the artifacts from the Louvre Museum belonged to the collection of Adolphe Thiers (1797-1877), former president of the French Republic. Indeed, following the Universal Exhibitions, the European elites of the second part of the 19th century took a great interest in Chinese and Japanese ceramics and built up collections rich in exceptional pieces. Most of the artifacts studied here were assigned, based on a stylistic examination of their shape and decor, to have been made during the Yongzheng reign (1722-1735) or just afterwards. The corpus studied includes four cups, five plates, one milk pot, one saucer lid, one teapot and three bottles, which were analyzed by Raman microspectrometry. Only the TH457 bottle was also analyzed by portable XRF (pXRF). Some of the artifacts have rather similar counterparts in other museum collections (Table 1). Four artifacts display painted enamel decor with exceptional quality, such as the plates with roosters (TH487, Figure 1) and tigers (R1056, Figure 2) and especially the TH457 (Figure 3), F1371C (Figure 4) and F1341C (Figure 5) bottles. Close-up views of the painted flower-and-bird decor on the TH457 bottle and the flower decor on the F1341C bottle and F1429C teapot display the high sharpness of the drawing without any diffusion of the colors outside the areas delimited by (black) lines. The F1371C bottle shows a technique inspired by cloisonné enameled metalware in which the decor is first made by incision in order to avoid diffusion of the colors, somewhat similar to the sgraffito technique. 
Table 1. Information about the studied artifacts regarding their collections and time assignments along with special remarks (see [25-27]).

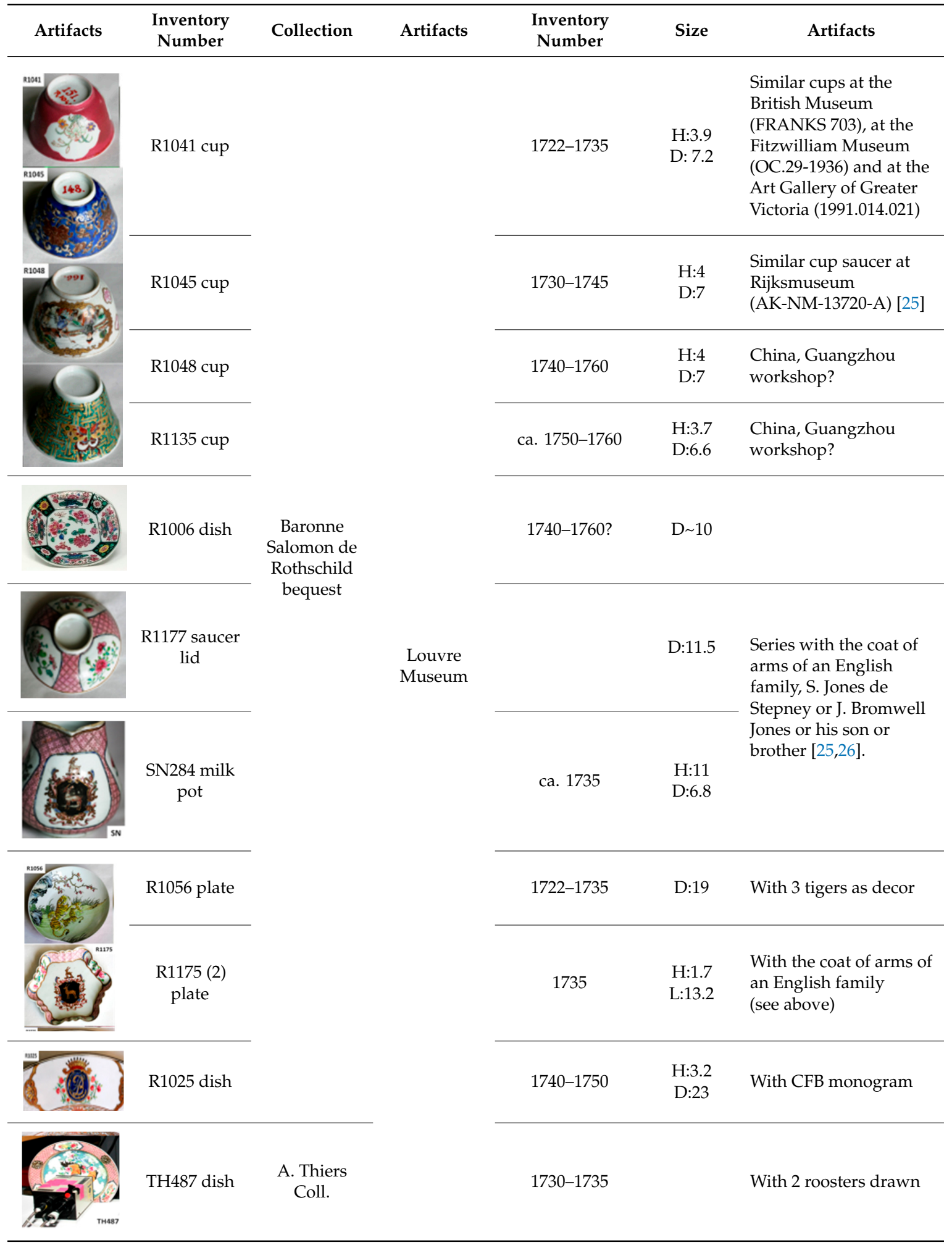


Table 1. Cont.

\begin{tabular}{|c|c|c|c|c|c|c|}
\hline Artifacts & $\begin{array}{l}\text { Inventory } \\
\text { Number }\end{array}$ & Collection & Artifacts & $\begin{array}{c}\text { Inventory } \\
\text { Number }\end{array}$ & Size & Artifacts \\
\hline & TH457 bottle & $\begin{array}{l}\text { A. Thiers } \\
\text { Coll. }\end{array}$ & & 1735-1796 & $\begin{array}{c}\mathrm{H}: 30.9 \\
\mathrm{D}: 12\end{array}$ & \\
\hline & $\begin{array}{c}\text { F1371C } \\
\text { bottle }\end{array}$ & \multirow{3}{*}{$\begin{array}{c}\text { Napoléon } \\
\text { Emperor } \\
\text { Coll. }\end{array}$} & \multirow{3}{*}{$\begin{array}{c}\text { Fontaine } \\
\text { bleau Castle } \\
\text { (Musée } \\
\text { Chinois) }\end{array}$} & $1730 / 35-1750 / 60$ & $\begin{array}{l}\text { H:19 } \\
\text { D:30 }\end{array}$ & \\
\hline & $\begin{array}{l}\text { F1429C } \\
\text { teapot }\end{array}$ & & & $\begin{array}{l}\text { Qianlong period } \\
\quad(1736-1795)\end{array}$ & $\begin{array}{l}\mathrm{H}: 13 \\
\mathrm{D}: 12 \\
\mathrm{~A}: 19\end{array}$ & \multirow{2}{*}{$\begin{array}{l}\text { Jingdezhen } \\
\text { Imperial } \\
\text { Factory } \\
\text { of Porcelain }\end{array}$} \\
\hline & $\begin{array}{c}\text { F1341C } \\
\text { bottle }\end{array}$ & & & $\begin{array}{c}\text { End of } \\
\text { Yongzheng } \\
\text { period } \\
(\sim 1730-1735)\end{array}$ & $\begin{array}{l}\mathrm{H}: 30 \\
\mathrm{D}: 15\end{array}$ & \\
\hline
\end{tabular}

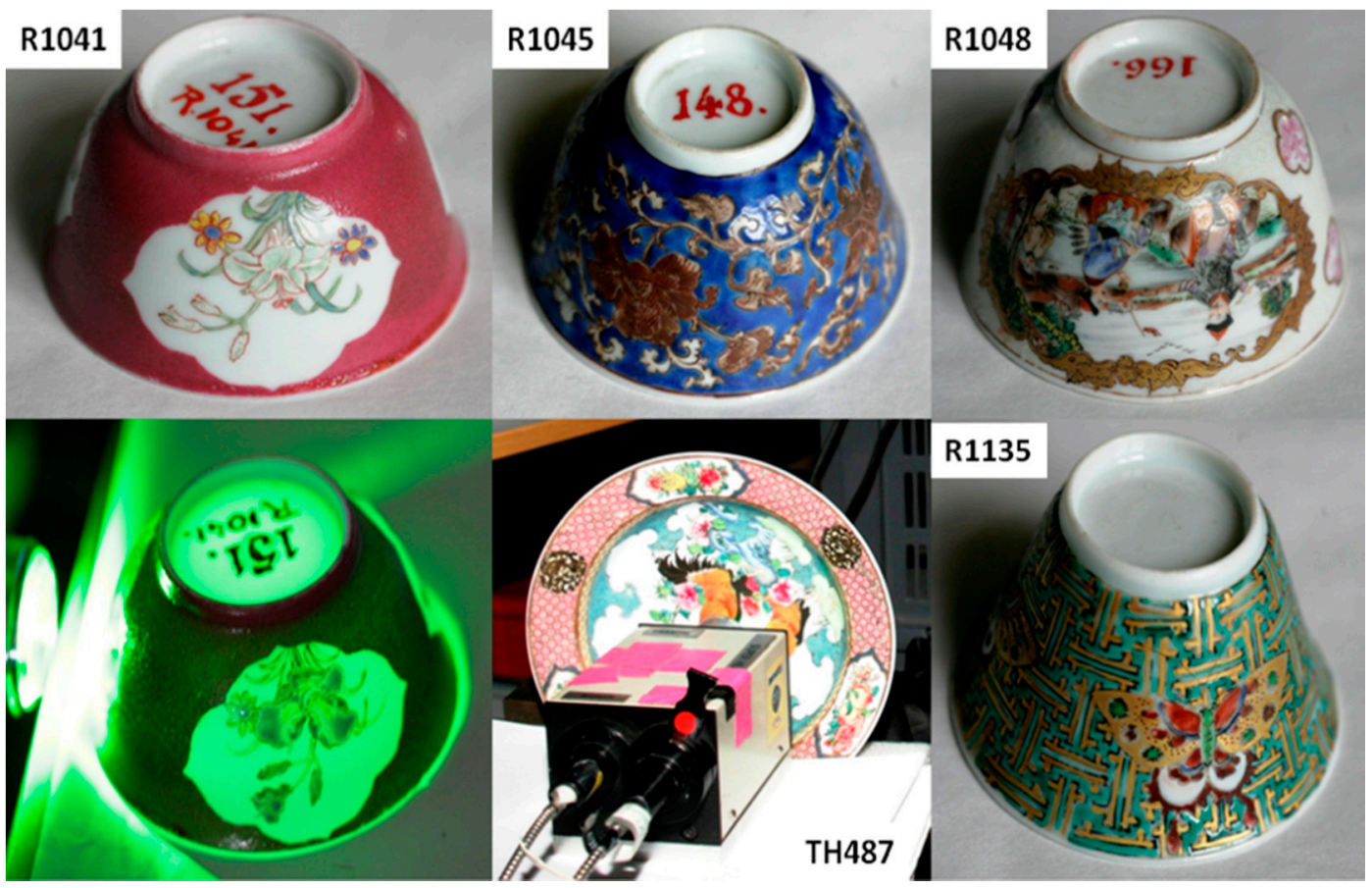

Figure 1. The cups and plate analyzed. The remote head with optic fibers connected to the laser source and the spectrometer is shown at the bottom. A laser focusing on the R1041 cup exhibits the high translucency of the porcelain (see Table 1 for details). 


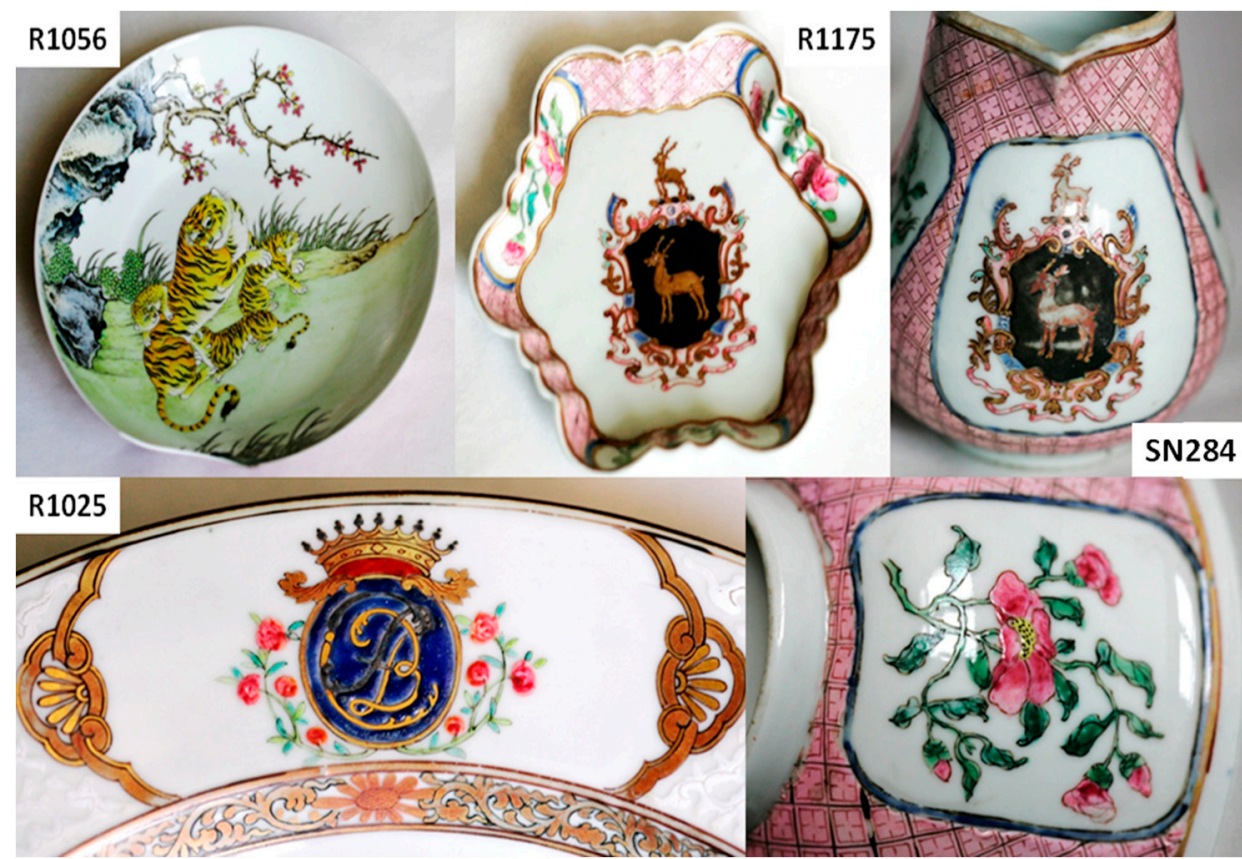

Figure 2. The detailed images of the plates and milk pot analyzed (see Table 1 for details).
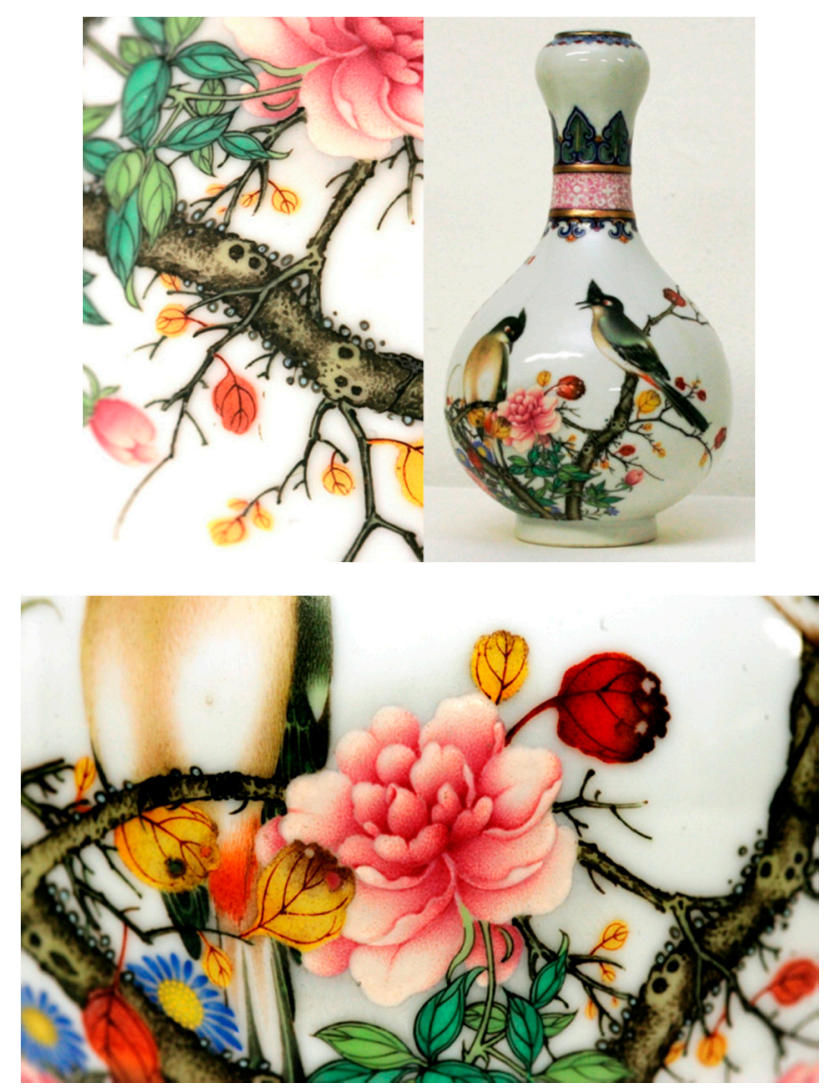

Figure 3. The detailed images of the TH457 bottle (the neck has undergone a restoration process; see Table 1 for details). 


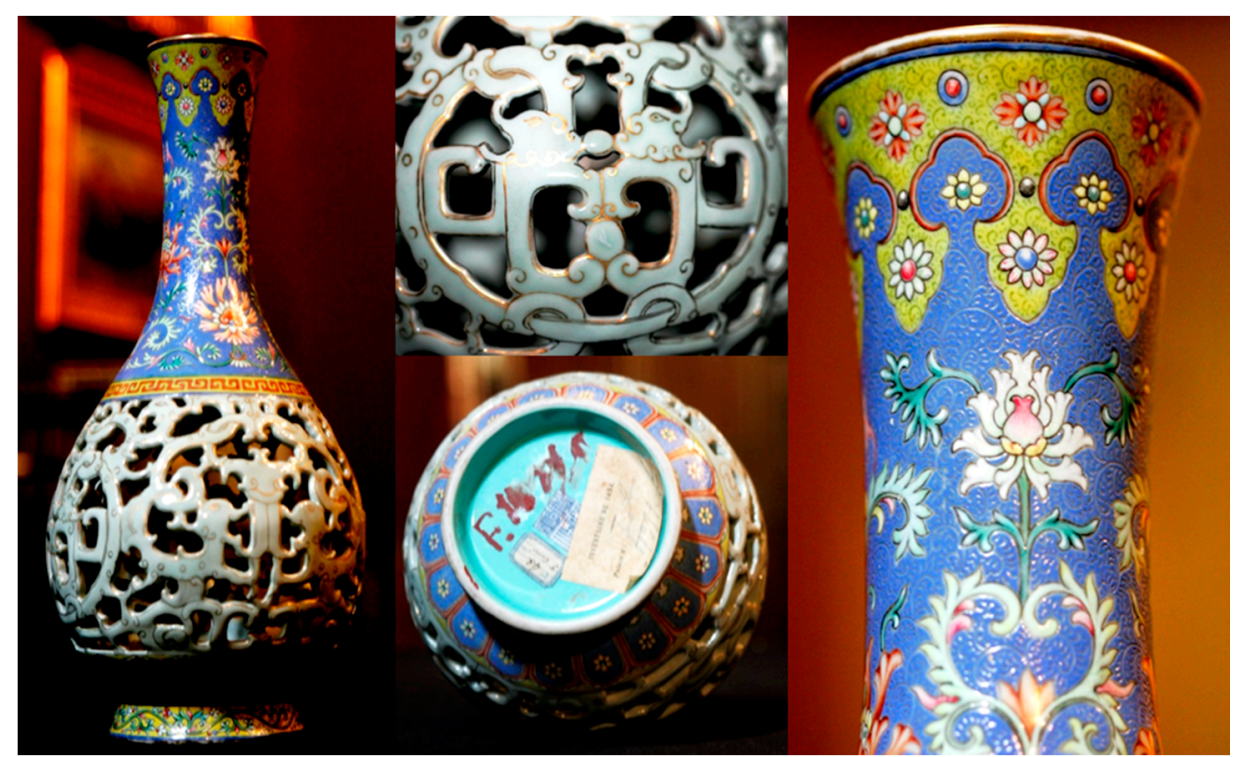

Figure 4. The detailed images of the bottle (F1371C; see Table 1 for details).

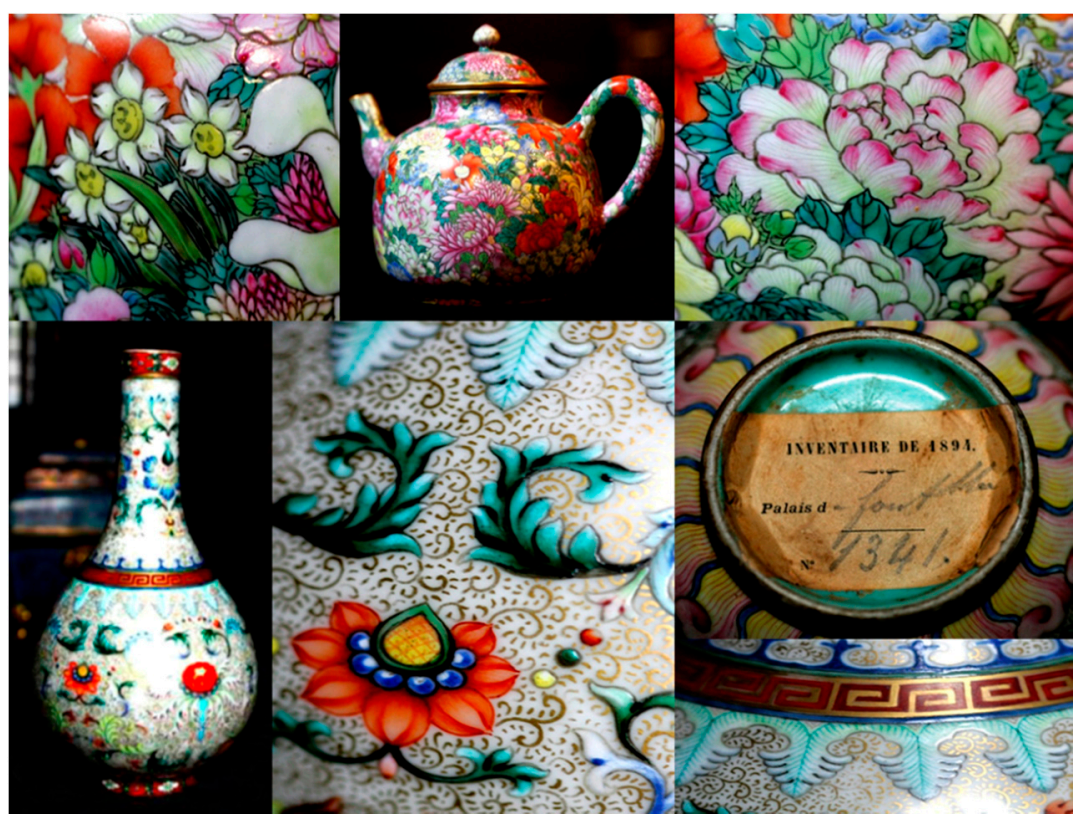

Figure 5. The detailed images of the teapot (F1429C, top) and bottle (F1341C, bottom); see Table 1 for details.

Different grades of the hue were obtained by adding minute dots of color in the TH457 bottle (Figure 3), as also observed in the painted enameled decor of 18th-century French watches [18]. This indicates the use of very small pencils. Consequently, the thickness of the painted enamel decor remains very thin. The technique used appears to be different from the common pottery technique of adjusting the hue of enameled decor by superimposing enamel layers relatively thickly, as is visible for the R1006, R1175, R1025, R1041, R1045 and SN284 artifacts (Figures 1 and 2). The technique used for the F1429C teapot (Figure 5) is an intermediate between the two techniques.

An examination of the section of porcelain shards exhibiting similar decor by optical microscopy or of the whole objects by optical coherence tomography studies (OCT) is needed to go further in the description of the enameling technique. 


\subsection{Mobile Raman Microspectrometry}

The high value of the porcelain artifacts made it necessary to conduct the noninvasive Raman analyses in the exhibition or storage rooms of the Musée du Louvre (Paris) and Musée Chinois (Fontainebleau Castle). A mobile Raman setup from HORIBA Scientific Jobin Yvon (Longjumeau, France) was used for the on-site measurements. This setup was composed of an HE532 spectrometer (920 lines/mm grating; resolution $\sim 4 \mathrm{~cm}^{-1}$ ), a remote optical device called SuperHead (Figure 1) and a $532 \mathrm{~nm} 300 \mathrm{~mW}$ Ventus laser source (Laser Quantum, Fremont, CA, USA), which were connected to each other by optic fibers. The SuperHead incorporates long working distance x50 (surface analyzed: $\sim 10-20 \mu \mathrm{m}^{2}$; in-depth: 5-20 $\mu \mathrm{m}$ ) and x200 (surface analyzed: $\sim 1 \mu \mathrm{m}^{2}$; in-depth: $\sim 1-2 \mu \mathrm{m}$ ) microscope objectives for the green laser illumination and the collection of scattered light. Details about the procedures have already been published $[13,17,18,20]$.

\subsection{Mobile X-ray Fluorescence Microspectrometry}

Portable XRF ( $\mathrm{pXRF)}$ measurements were performed without any contact between the instrument and the artifact using an ELIO instrument (ELIO, XGLab/Bruker, Italy). This setup consisted of a miniature X-ray tube system with a Rh anode (max voltage of $50 \mathrm{kV}$, max current of $0.2 \mathrm{~mA}$, a $1 \mathrm{~mm}$ collimator determining a rather similar surface) and a large-area silicon drift detector (SDD) (50 $\mathrm{mm}^{2}$ active area). Details about the procedure have already been published; it should be noted the information thickness during the analysis of the enamel was estimated to be $\sim 4 \mu \mathrm{m}$ at $\mathrm{Si} \mathrm{K}_{\alpha}, 130 \mu \mathrm{m}$ at $\mathrm{Cu} \mathrm{K}{ }_{\alpha}, 220 \mu \mathrm{m}$ at $\mathrm{Au} \mathrm{L}_{\alpha}$ and $\sim 2.5 \mathrm{~mm}$ at $\mathrm{Sn} \mathrm{K}_{\alpha}$ [18].

\section{Results and Discussion}

\subsection{Body Phase Identification}

Raman spectra (Figures 6-13) have been recorded on the glaze-free body for the different artifacts (see Figure 6A (R1045), Figure 7A (TH457), Figure 8B (R1175) and Figure 9A,B (R1006 and SN284)). In these spectra, the narrow main peak of quartz $\left(\mathrm{SiO}_{2}\right)$ was observed at ca. $460 \mathrm{~cm}^{-1}[28,29]$, shifted down to lower wavenumbers than that of the isolated quartz mineral $\left(\sim 463 \mathrm{~cm}^{-1}\right)$ due to the compressive stress of the glassy matrix on the quartz grains. A broader component at ca. $480 \mathrm{~cm}^{-1}$ was also observed (see e.g., Figures 7A and 9B), characteristic of a glassy aluminosilicate phase forming the porcelain body in between acicular mullite crystals forming a 3D network [30,31]. The mullite phase was generally not detected with a mobile Raman spectrometer due to the operating conditions of the mobile setup and poor intensity of the mullite Raman spectrum. Only in the body spectrum of the R1045 cup (Figure 6A(a)) could very small features at $~ 960$ and $1130 \mathrm{~cm}^{-1}$ be considered to come from the mullite phase [28]. The Raman spectrum of the glaze, fired at a high temperature with the porcelain body, was rather similar, but the intensity of the $\sim 490$ to $505 \mathrm{~cm}^{-1}$ broad component was stronger, and the quartz peak was mostly weaker, as observed for the glaze spectra of the R1045 and R1041 cups (Figure 6A(b),C(b)). 

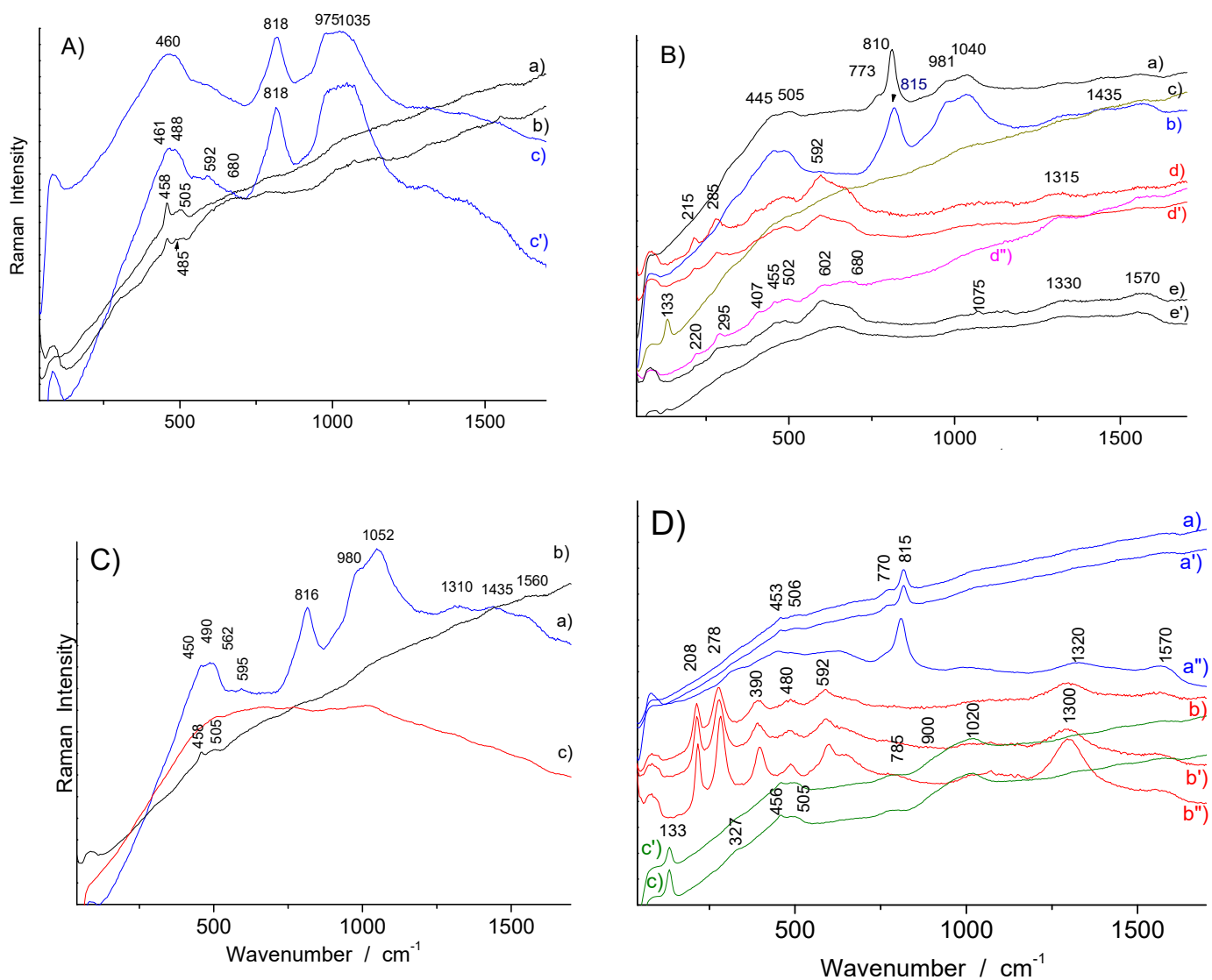

Figure 6. Representative Raman spectra recorded on the body, glaze and painted enamels of the porcelains: (A) R1045 cup (a) body, (b) white, (c,c') blue; (B) R1048 cup (a) white, (b) blue, (c) yellow, (d,d',d") red, (e,e') black (line); (C) R1041 cup (a) blue (flower), (b) colorless glaze, (c) pink; (D) R1135 cup $\left(a, a^{\prime}, a^{\prime \prime}\right)$ blue, $\left(b, b^{\prime}, b^{\prime \prime}\right)$ red (eye), $\left(c, c^{\prime}\right)$ green areas.
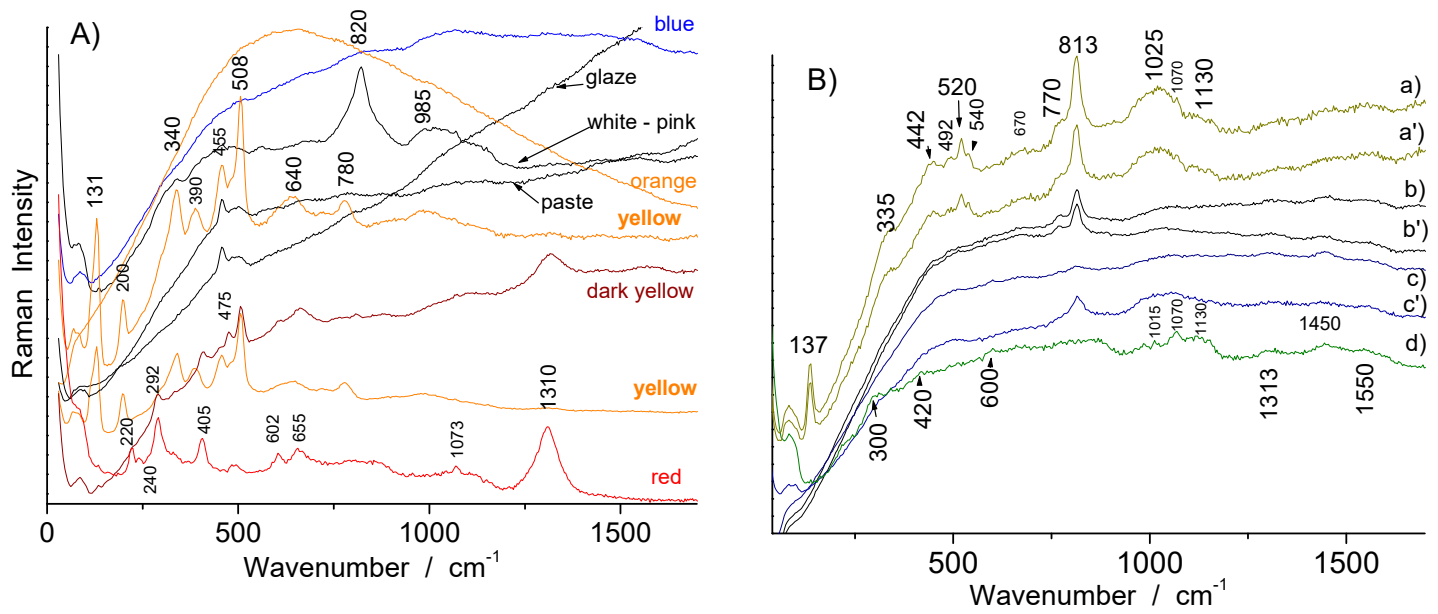

Figure 7. Representative Raman spectra recorded on the body, glaze and painted enamels of the TH457 (A) and F1371C bottles (B): (a, $\left.\mathrm{a}^{\prime}\right)$ white, (b, $\left.\mathrm{b}^{\prime}\right)$ dark blue, (c, $\mathrm{c}^{\prime}$ ) celadon (green), (d) yellow-green. 

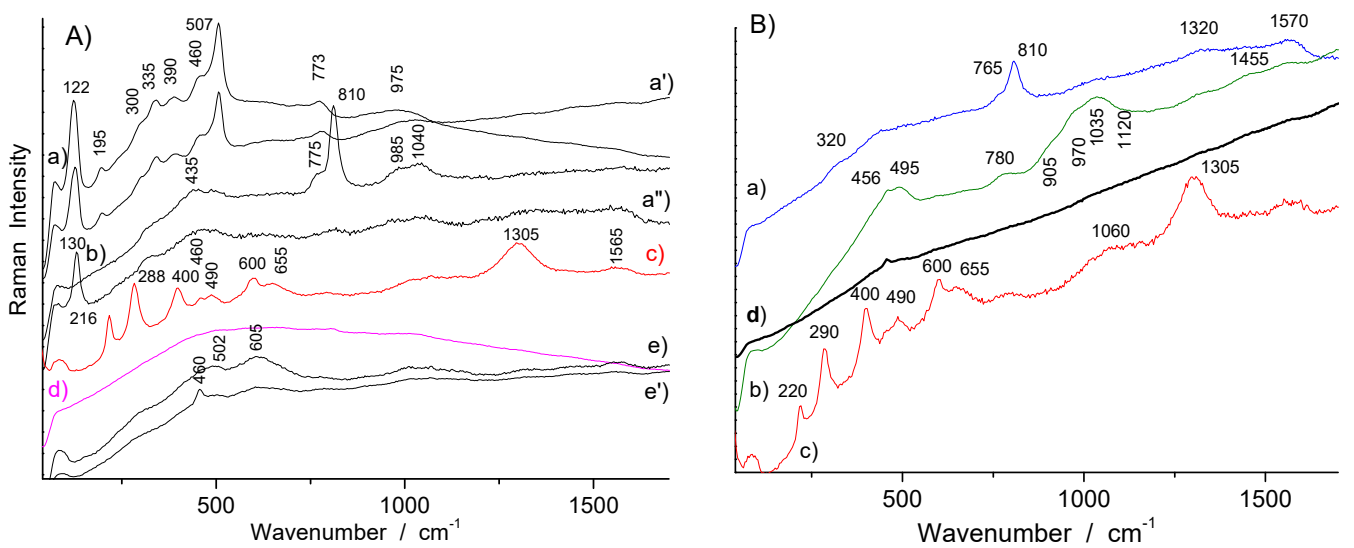

Figure 8. Representative Raman spectra recorded on the painted enamels of the R1175 large plate (A) (a,a',a") (marli) yellow, (b) (marli) blue, (c) orange (coat), (d) red (flower), (e,e') (marli) black; and small plate (B) (a) blue, (b) green, (c) red (line), (d) body.
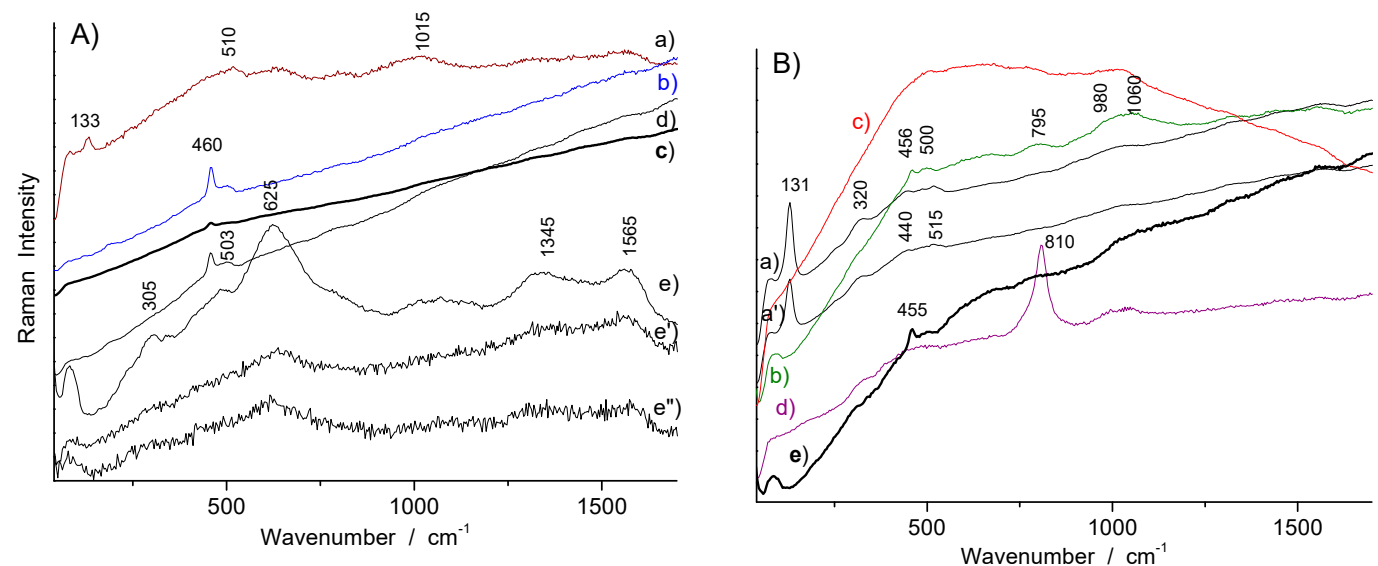

Figure 9. Representative Raman spectra recorded on the body, glazes and painted enamels of the R1006 dish (A) (a) light yellow, (b) blue glaze, (c) colorless glaze, (d) body, (e,e', $\left.\mathrm{e}^{\prime \prime}\right)$ black (e' and e" corresponded to very short counting times, and e, to 500 accumulations); and SN284 pot (B) (a,a') yellow, (b) green, (c) red (flower), (d) pink (textile), (e) body.
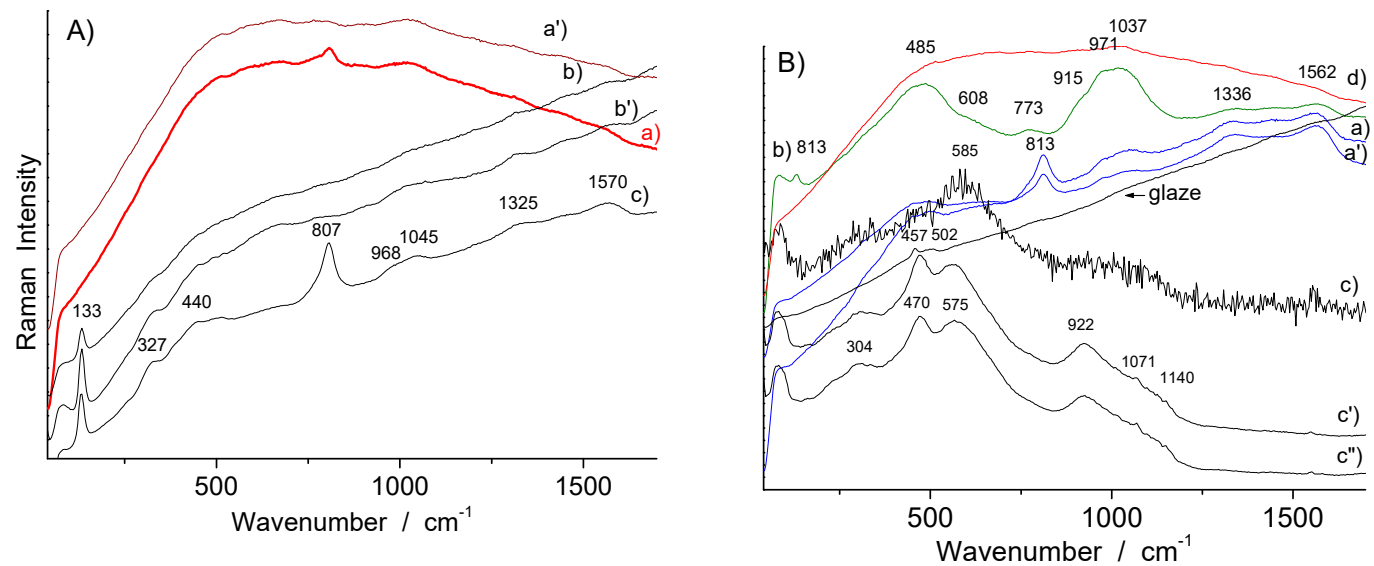

Figure 10. Representative Raman spectra recorded on the painted enamels of the TH487 plate: (A) (a, $\left.a^{\prime}\right)$ red, (b, $b^{\prime}$ ) yellow (cock), (c) (marli) light yellow; (B) (a,a') blue, (b) green, $\left(c, c^{\prime}, c^{\prime \prime}\right)$ black (c, very short counting time), (d) red. 

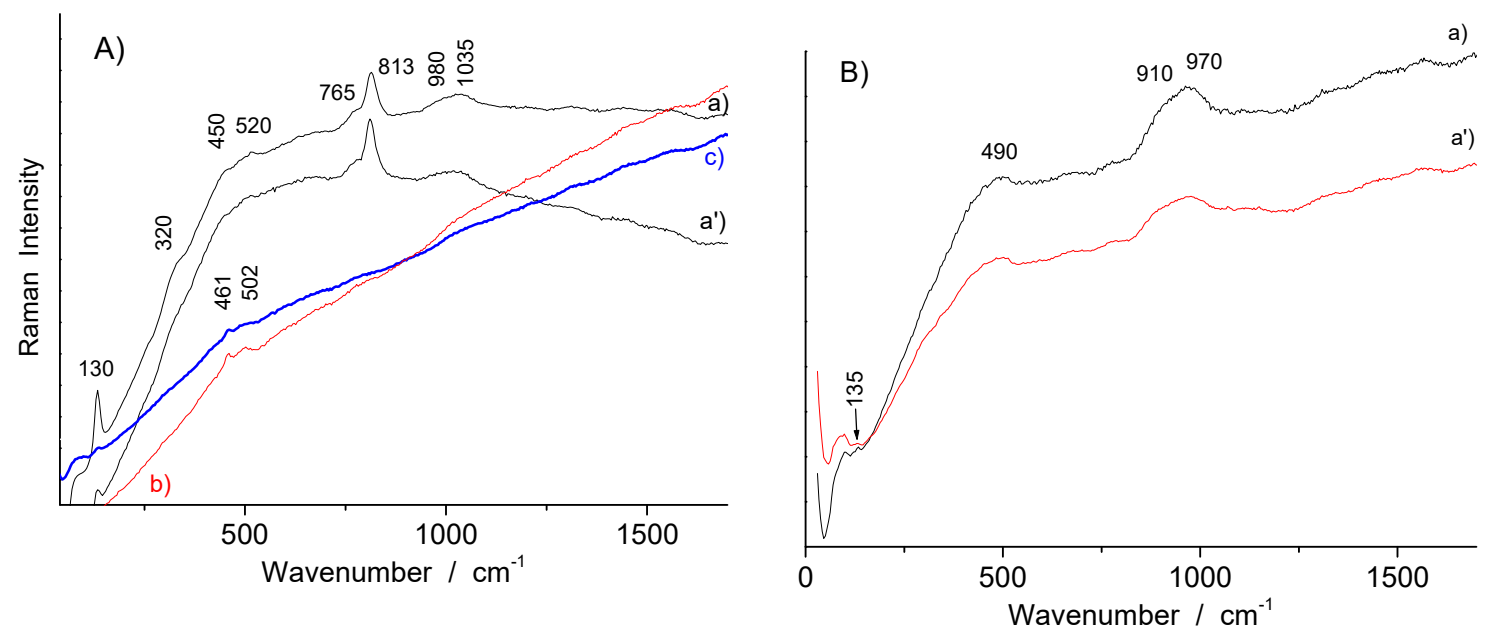

Figure 11. Representative Raman spectra recorded on the glaze and painted enamels of the R1056 tiger plate (A) (a,a') white (tiger belly), (b) pink, (c) glaze; and SN284 pot (B) yellow.
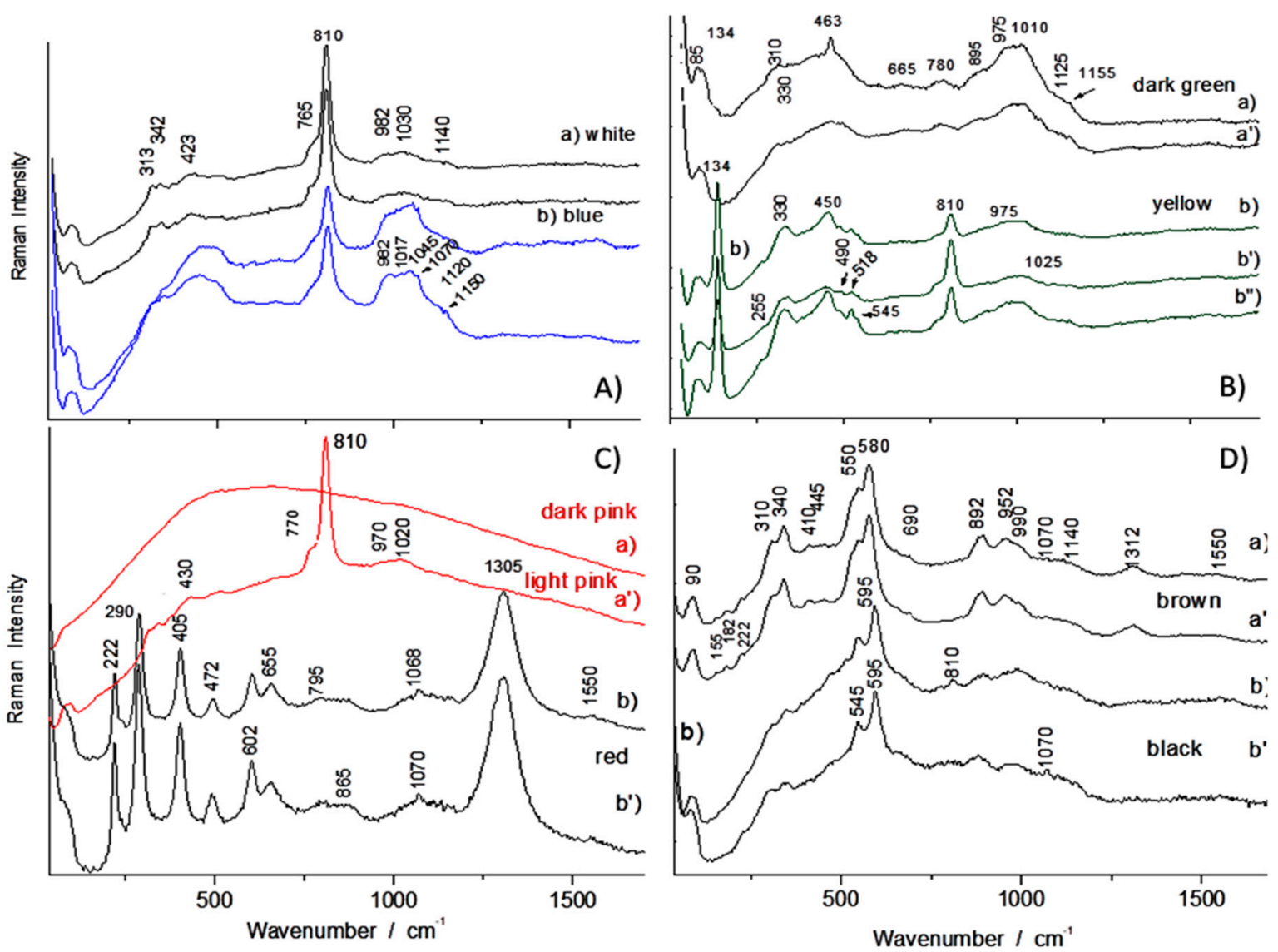

Figure 12. Representative Raman spectra recorded on the F1429C teapot for different colored painted enamels: (A) white (a) and blue (b) enamels; (B) dark green $\left(a, a^{\prime}\right)$ and yellow (b, $\left.b^{\prime}, b^{\prime \prime}\right)$ enamels; (C) pink $\left(\mathrm{a}, \mathrm{a}^{\prime}\right)$ and red $\left(\mathrm{b}, \mathrm{b}^{\prime}\right)$ enamels; (D) brown $\left(\mathrm{a}, \mathrm{a}^{\prime}\right)$ and black $\left(\mathrm{b}, \mathrm{b}^{\prime}\right)$ enamels. 

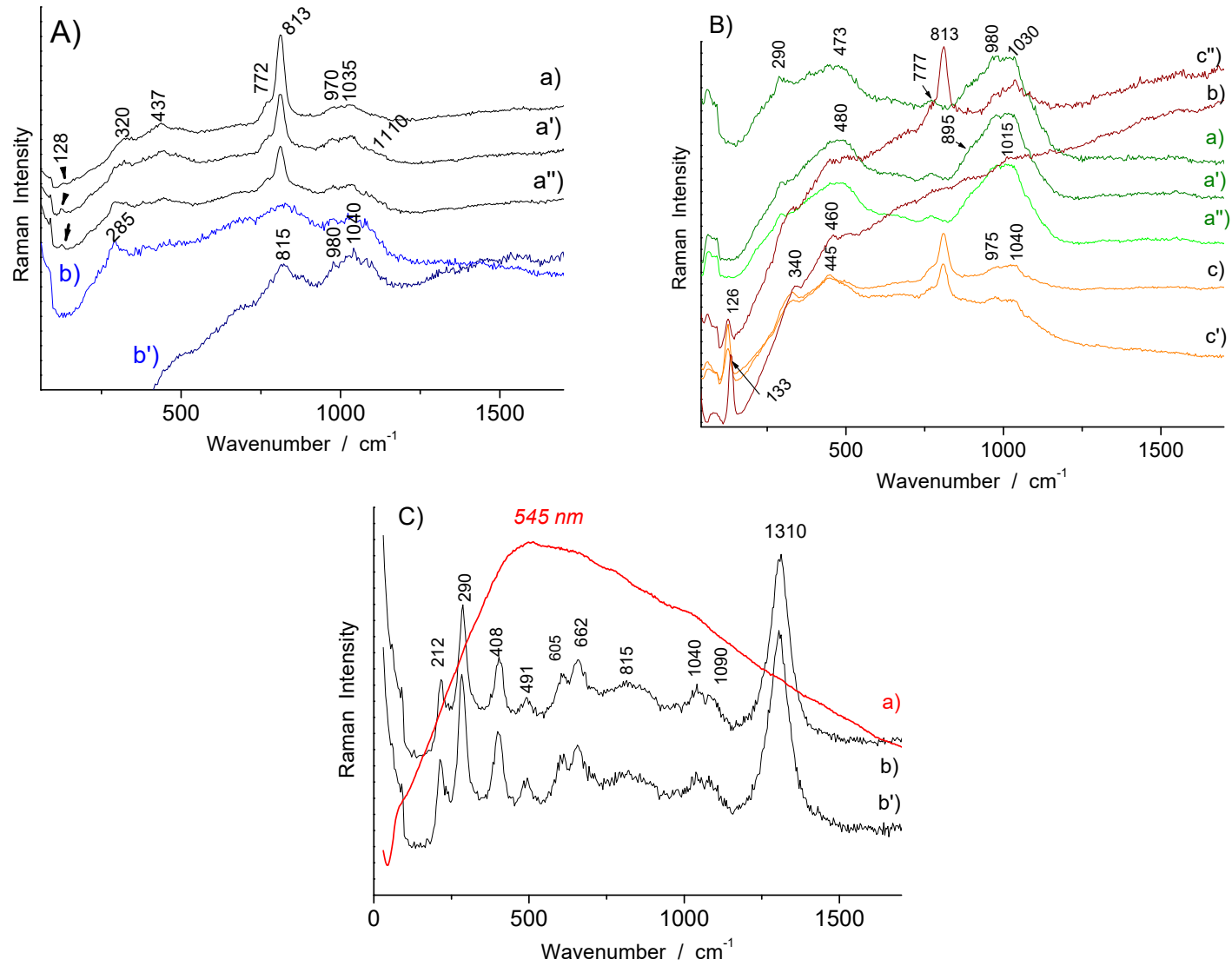

Figure 13. Representative Raman spectra recorded on the painted enamels of the F1341C bottle: (A) white $\left(\mathrm{a}, \mathrm{a}^{\prime}, \mathrm{a}^{\prime \prime}\right)$ and blue $\left(\mathrm{b}, \mathrm{b}^{\prime}\right)$; (B) green (a, $\mathrm{a}^{\prime}, \mathrm{a}^{\prime \prime}$ light green) and yellow (b,c, $\left.\mathrm{c}^{\prime}, \mathrm{c}^{\prime \prime}\right)$; (C) orange (a) and red $\left(b, b^{\prime}\right)$.

\subsection{Phase Identification in Colored Glaze/Enamels}

Different phases were identified by Raman analysis for the different colored areas of the Chinese painted enameled porcelains, such as white, blue, yellow (and green), red (purple to red) and pink (Table 2).

Table 2. Characteristic pigments/opacifiers identified in the different colored painted enamels (overglaze) of the Chinese porcelains analyzed. The decor made with imported European recipes is expressed in bold (NY: Naples yellow, br: broad, nr: narrow, sh: shoulder, s: small).

\begin{tabular}{|c|c|c|c|c|}
\hline Color & Artifact & Identified Phase(s) & $\begin{array}{c}\text { Characteristic Raman } \\
\text { Peak }\left(\mathrm{cm}^{-1}\right)\end{array}$ & Remarks \\
\hline \multirow[b]{2}{*}{$\begin{array}{l}\text { White (colorless } \\
\text { glaze) }\end{array}$} & \multirow{2}{*}{$\begin{array}{l}\text { R1006, R1041, } \\
\text { R1056, R1175, } \\
\text { TH457, TH487 }\end{array}$} & quartz & $455-460$ & \\
\hline & & $\begin{array}{c}\text { glassy } \\
\text { aluminosilicate }\end{array}$ & $\sim 485$ (br) & \\
\hline White (overglaze) & $\begin{array}{l}\text { F1371C, R1048, } \\
\text { R1056 }\end{array}$ & As apatite & $\sim 813(\mathrm{nr}), \sim 770(\mathrm{sh})$ & White type 1 \\
\hline $\begin{array}{l}\text { White-pink } \\
\text { (overglaze) }\end{array}$ & TH457 & arsenate & 820 (br) & White type 2 \\
\hline \multirow{2}{*}{ Blue (overglaze) } & $\begin{array}{l}\text { R1175 (s), R1135, } \\
\text { F1371C, F1429C }\end{array}$ & As apatite & $\sim 810(\mathrm{nr}), \sim 775(\mathrm{sh})$ & Blue type 1 \\
\hline & $\begin{array}{l}\text { TH487, R1045, } \\
\text { R1048, R1041 }\end{array}$ & arsenate & $\sim 815$ (br) & Blue type 2 \\
\hline
\end{tabular}


Table 2. Cont.

\begin{tabular}{|c|c|c|c|c|}
\hline Color & Artifact & Identified Phase(s) & $\begin{array}{c}\text { Characteristic Raman } \\
\text { Peak }\left(\mathrm{cm}^{-1}\right)\end{array}$ & Remarks \\
\hline Blue (glaze) & R1006 & $\begin{array}{c}\text { glassy silicate }(+ \\
\text { quartz) }\end{array}$ & 460,503 & $\begin{array}{c}\text { Blue type } 3 \\
\text { Smalt? }\end{array}$ \\
\hline \multirow{4}{*}{ Yellow (overglaze) } & R1175, TH457 & $\begin{array}{l}\text { Sb-rich NY } \\
\text { pyrochlore }\end{array}$ & $\sim 122 / 130, \sim 335,508$ & \\
\hline & $\begin{array}{l}\text { R1175, R1006, } \\
\text { R1048, TH487, } \\
\text { SN284, R1135 }\end{array}$ & $\begin{array}{l}\text { Sn-rich NY } \\
\text { pyrochlore }\end{array}$ & $\sim 130-133, \sim 455$ & \\
\hline & TH487, R1056 & $\begin{array}{l}\text { Sn-rich NY } \\
\text { pyrochlore }+ \\
\text { arsenate }\end{array}$ & $\begin{array}{c}\sim 133,327,440, \\
\sim 810-820 \text { (broad) }\end{array}$ & \\
\hline & $\begin{array}{c}\text { F1429C, F1341C?, } \\
\text { TH457 }\end{array}$ & $\begin{array}{l}\mathrm{Sb}-\mathrm{Sn}-(\mathrm{Zn}, \mathrm{Fe} ?) \\
\mathrm{NY} \text { pyrochlore }+ \\
\text { As apatite }\end{array}$ & $\begin{array}{c}134,330,450,480-490 \\
518, \\
810,770(\mathrm{sh})\end{array}$ & \\
\hline $\begin{array}{l}\text { Yellow-green } \\
\text { (overglaze) }\end{array}$ & R1135 & $\begin{array}{l}\text { Sn-rich NY } \\
\text { pyrochlore + } \\
\text { As-apatite }\end{array}$ & $\begin{array}{l}\sim 133,330 \\
815,770\end{array}$ & \\
\hline Green (overglaze) & R1135 & $\begin{array}{l}\text { Sn-rich NY } \\
\text { pyrochlore }\end{array}$ & 130-133, 330, 455 & \\
\hline $\begin{array}{l}\text { Blue-green } \\
\text { (overglaze) }\end{array}$ & TH487 & $\begin{array}{l}\text { Sn-rich NY } \\
\text { pyrochlore }+ \\
\text { arsenate }\end{array}$ & $\begin{array}{l}\sim 133,330,440 \\
\sim 810\end{array}$ & \\
\hline $\begin{array}{l}\text { Dark yellow } \\
\text { (overglaze) }\end{array}$ & TH457 & $\begin{array}{l}\text { Feldspar? } \\
\text { + hematite }\end{array}$ & $\begin{array}{c}\sim 508 \\
+220,292, \sim 1310\end{array}$ & \\
\hline \multirow[b]{2}{*}{ Red (overglaze) } & $\begin{array}{l}\text { TH457, R1175, } \\
\text { R1048, R1135 }\end{array}$ & hematite & $220,292, \sim 1310$ & \\
\hline & $\begin{array}{l}\text { SN284, R1175 } \\
\text { (large), TH487 }\end{array}$ & $\mathrm{Au}^{\circ}+$ arsenate & $\begin{array}{c}\text { Fluorescence } \\
\text { background peaking at } \\
\sim 500+\sim 810\end{array}$ & \\
\hline \multirow[t]{3}{*}{$\begin{array}{c}\text { Orange } \\
\text { (overglaze) }\end{array}$} & TH457, SN284 & $\mathrm{Au}^{\circ}$ & $\begin{array}{c}\text { Fluorescence } \\
\text { background peaking at } \\
\sim 600\end{array}$ & \\
\hline & $\begin{array}{l}\text { R1175, R1041, } \\
\text { TH487 }\end{array}$ & $\mathrm{Au}^{\circ}+$ arsenate & $\begin{array}{c}\text { Fluorescence } \\
\text { background }+\sim 820\end{array}$ & \\
\hline & R1175 & hematite & $220,290, \sim 1305$ & \\
\hline \multirow[t]{2}{*}{$\begin{array}{l}\text { Pink (rose) } \\
\text { (overglaze) }\end{array}$} & SN284 & Arsenate $+\mathrm{Au}^{\circ} ?$ & $\begin{array}{c}\sim 810+ \\
\text { fluorescence } \\
\text { background at } \sim 500\end{array}$ & \\
\hline & R1041, F1429C & $\mathrm{Au}^{\circ}$ & $\begin{array}{c}\text { Fluorescence } \\
\text { background at } \sim 500\end{array}$ & \\
\hline \multirow{3}{*}{ Black (overglaze) } & TH487 & Mn oxide & $470-575$ & \\
\hline & $\begin{array}{l}\text { R1175, R1048, } \\
\text { TH487 }\end{array}$ & $\begin{array}{l}\text { Mn spinel/oxide (+ } \\
\text { carbon) }\end{array}$ & $\begin{array}{c}502-605 \\
(+1330-1570) \\
\end{array}$ & \\
\hline & R1006 & $\begin{array}{l}\text { Spinel (Mn?) (+ } \\
\text { carbon) }\end{array}$ & $625(+1330-1565)$ & \\
\hline Brown & F1429C & Mn oxide & $550,580,892$ & \\
\hline
\end{tabular}




\subsubsection{Arsenic-Based Phases}

In the painted enamels analyzed, the detection of two types of arsenic-based phases was significant. The first type refers to lead alkali arsenate apatite, recognized with the narrow (ca. $810-813 \mathrm{~cm}^{-1}$ ) peak and a well-defined shoulder at $\sim 770-775 \mathrm{~cm}^{-1}[12-14,17,18,32-34]$, characteristic of the As-O stretching mode of apatite, for which a composition close to $\mathrm{Na}_{1-\mathrm{x}-\mathrm{y}} \mathrm{K}_{\mathrm{x}} \mathrm{Ca}_{\mathrm{y}} \mathrm{Pb}_{4}\left(\mathrm{AsO}_{4}\right)_{3}(\mathrm{x}=0.1$ and $\mathrm{y}=0.5)$ has been deduced in a French soft-paste porcelain [34]. This type of opacifying phase was found in some of the enamels analyzed, mostly in white and blue as well as light pink and yellow ones $[11-14,17,18,34]$, as observed in Figure 6B(a) (R1048), Figure 6D(a,a') (R1135), Figure 7B(a,a'),(b,b') (F1371C), Figure 8A(b), Figure 8B(a) (R1175), Figure 10A(a), Figure 11A(a,a'), Figure 12A(a,b), Figure 12B(b, b', b') and Figure 12 $\mathrm{C}\left(\mathrm{a}^{\prime}\right)$ (F1429C). In the case of blue enamels, lead arsenate apatite typically forms as a result of a reaction between arsenic coming from the cobalt source (smalt) and the lead-based enamel/glaze (see further) during the firing process. Its composition also depends on various fluxing species, such as $\mathrm{Na}(\mathrm{K})$ and $\mathrm{Ca}$, present in the enamel/glaze matrix [3]. Raman spectra of these enamels displayed the characteristic signature of lead arsenate apatite along with that of the glassy silicate matrix, indicating that the blue was obtained by dissolution of $\mathrm{Co}^{2+}$ ions in the glassy matrix [29]. The bands expected due to the precipitation of cobalt aluminate or cobalt silicate (see further) were also not detected. Cobalt ores with an arsenic-rich composition are characteristic of European sources used between 1500 and 1800 [17,18,35,36]. In particular, raw cobalt arsenide mined from the Erzgebirge (the Ore Mountains) in Saxony (Germany) were mixed with potassium glass to produce blue smalt, which was then exported as a coloring agent for glasses/enamels and paint for easel paintings during the 16th-17th centuries $[3,36,37]$. The detection of lead arsenate apatite could also be due to deliberate addition of an arsenic compound for opacification, especially in the case of the white enamels analyzed [34]. This phase has also been identified in the previous analytical studies of 18th-19th-century Chinese porcelains produced during the Qing dynasty [11-14] as well as in the blue decor of 17th- and 18th-century French enameled glass [16], enameled metalware [10,11,18] and soft-paste porcelains [17,34].

The second type of arsenate phase was characterized by a much broader (ca. $815-820 \mathrm{~cm}^{-1}$ ) peak (Figure 6A(c,c') (R1045 blue), Figure 6B(b) (R1048 blue), Figure 6C(a) (R1041 blue), Figure 7A (TH457 white-pink), Figure 10A(c) (TH487 yellow) and Figure 13A(b') (F1341C blue)). An intermediate shape between those of the two arsenate phases was observed for Figure 9B(d) (SN284 pink). This broad arsenate band has already been observed in Kangxi Chinese porcelains for the blue areas [12-14] as well as certain French enameled productions [11,16-18]. The broadening of the As-O stretching modes may have arisen from the poor crystallinity or small size of the arsenate apatite crystals or from structural distortions differentiating the $\mathrm{AsO}_{4}$ tetrahedra (only one strong peak with $\mathrm{A}_{1}$ symmetry is expected for the stretching mode of an $\mathrm{XO}_{4}$ tetrahedron). However, arsenates with different composition and structures from apatites (e.g., feldspar) have also been identified in Italian and Spanish majolica enamels [38-41]. Microdestructive analyses to be performed on porcelain shards, such as $\mu$-diffraction, $\mu \mathrm{XRF}$ and/or transmission electron microscopy analyses, are needed to identify more precisely the arsenic-based phases given the ca. $815 \mathrm{~cm}^{-1}$ broad band.

The two signatures observed in the blue enameled areas indicated the use of cobalt ores rich in arsenic, i.e., cobalt ores imported from Europe [11,15-18] or a mixture of Asian (Mn- and Fe-rich) $[3,13,36,42-46]$ and European (As-rich) cobalt ingredients. However, the rareness-and high cost-of European ingredients led Japanese potters, and likely Chinese ones, to mix with Asian ingredients. This point will be discussed further using the XRF spectra obtained.

\subsubsection{Lead Pyrochlore (Naples Yellow)}

A second important outcome of this study was the detection of at least two types of Naples yellow lead pyrochlore pigments in the yellow and green painted enamels of the porcelains. Naples yellow refers to a variety of synthetic lead antimonate pigments with a pyrochlore structure, prepared by mixing lead oxide with various compounds, including mainly antimony and tin, in the presence of various fluxing agents $[1,3,12,13,18,47-54]$. This pigment, in the form of Sb- or Sn-rich types, 
has been used as a glass and glaze pigment since antiquity [55-57] and as a painting pigment after the Quattrocento/Renaissance [53,54]. Possible variations of the pigment might also include the addition of zinc, iron and silicon elements $[14,18,49,50]$. The adjustment of the proportions of these compounds at varying firing temperatures allows for the production of modified forms of the pigment displaying different hues. The composition of Naples yellow type pigments is therefore nonstoichiometric with the incorporation of various cations into the lead pyrochlore structure $\left(\mathrm{Pb}_{2-\mathrm{x}} \mathrm{M}_{\mathrm{X}}^{\prime} \mathrm{M}_{2-\mathrm{Y}} \mathrm{M}^{\prime \prime}{ }_{\mathrm{Y}} \mathrm{O}_{7-\delta}\right.$ with $\mathrm{M}, \mathrm{M}^{\prime \prime}=\mathrm{Sb}, \mathrm{Sn}, \mathrm{Fe}, \mathrm{Si}, \mathrm{Zn} ; \mathrm{M}^{\prime}=\mathrm{RE}$ ). This phase is built with two sublattices, one of (big) $\mathrm{Pb}^{2+}$ cations, the second of (small, covalent-bonded) cations forming tetrahedral and octahedral entities sharing some oxygen atoms. During the firing process of the enamels, composition of the pigment used may be further affected with other species present in the enamel matrix (Fe, Si, Sn, etc.) $[14,18,50,58,59]$. Some of these incorporating elements may also have different speciations (e.g., $\mathrm{Sn}^{2+} \mathrm{or} \mathrm{Sn}^{4+}, \mathrm{Sb}^{3+}$ or $\mathrm{Sb}^{5+}$, $\mathrm{Fe}^{2+}$ or $\left.\mathrm{Fe}^{3+}\right)$, and furthermore, the oxygen nonstoichiometry very much depends on the conditions of the firing process (reducing/oxidizing conditions).

In practice, the lead pyrochlore pigment can be prepared as a powder in advance and then mixed with the glass/glaze powder before deposition, the so-called "anime" and "corpo" recipes [57,60,61]. Alternatively, all the ingredients can be mixed together to obtain the yellow glass/glaze powder. In the first method, the grains of lead pyrochlore are rather big $(>>\mu \mathrm{m})$, while in the other, the homogeneous nucleation on cooling gives rise to small precipitates $(<\mathrm{a}$ few $\mu \mathrm{m})$. With a high-magnification microscope objective, a single pigment grain could be analyzed, and the Raman spectrum obtained was strong without a background, and almost no signature of the glassy matrix was recorded (see e.g., Figure 7A-TH457 yellow; see also in ref. [34]). In the case of nucleation, both the signature of lead pyrochlore precipitates and glass were recorded together with a significant background (e.g., Figure $\left.6 \mathrm{D}\left(\mathrm{c}, \mathrm{c}^{\prime}\right)\right)$.

In the last decades, several Raman spectrometry studies performed on various pottery glazes, glasses and enamels [1-3,11-18,47-52,57-59] as well as oil paintings [53-56] allowed for the identification of Naples yellow lead pyrochlore pigments. In general, these pigments have a very characteristic Raman signature, which basically includes the strong stretching mode peaks of $\mathrm{Pb}$ ions at the low-wavenumber region $\left(\sim 115-145 \mathrm{~cm}^{-1}\right)$ and $\mathrm{M} / \mathrm{M}^{\prime \prime}-\mathrm{O}$ stretching modes from $\sim 300$ to $600 \mathrm{~cm}^{-1}$. Furthermore, Sb-rich pyrochlore pigment is mainly distinguished by strong peaks at $\sim 110-130$ and $\sim 505 \mathrm{~cm}^{-1}$, while Sn-rich-type pigment exhibits stronger peaks at $\sim 130-135, \sim 335$ and $450 \mathrm{~cm}^{-1}$ (the Sn-O stretching mode) with the disappearance of the $\sim 505 \mathrm{~cm}^{-1}$ peak $[10,13,18,47-52]$. Zn-containing mixed lead pyrochlores exhibit a medium $450-480 \mathrm{~cm}^{-1}$ component [18]. Although Sn-rich lead pyrochlore was observed in most of the yellow and green enameled areas (Figure $6 \mathrm{~B}(\mathrm{c})$ (R1048), Figure 6D(c, $\left.c^{\prime}\right)(R 1135)$, Figure 9A(a) (R1006), Figure 9B(a, $\left.a^{\prime}\right)(S N 284)$, Figure 10A(b, b') (TH487), Figure 11A(a) (R1056) and Figure 13B(c, $\left.\mathrm{c}^{\prime}\right)(\mathrm{F} 1341 \mathrm{C})$ ), Sb-rich compositions were clearly observed in the yellow enamels of the TH457 bottle from the Thiers Collection (Figures 3 and 7A) and the R1175 plate with an English family's coat of arms (Figures 2 and $8 \mathrm{~A}\left(\mathrm{a}, \mathrm{a}^{\prime}\right)$ ). Mixed lead pyrochlores were also observed in some cases (Figure $7 \mathrm{~B}\left(\mathrm{a}, \mathrm{a}^{\prime}\right)(\mathrm{F} 1371 \mathrm{C})$ and Figure $12 \mathrm{~B}\left(\mathrm{~b}, \mathrm{~b}^{\prime}, \mathrm{b}^{\prime \prime}\right)(\mathrm{F} 1429 \mathrm{C})$ ). As a second piece of proof, the XRF spectrum recorded on the yellow enamel of TH457 showed both Sn and Sb signals (Figures 14 and 15). 


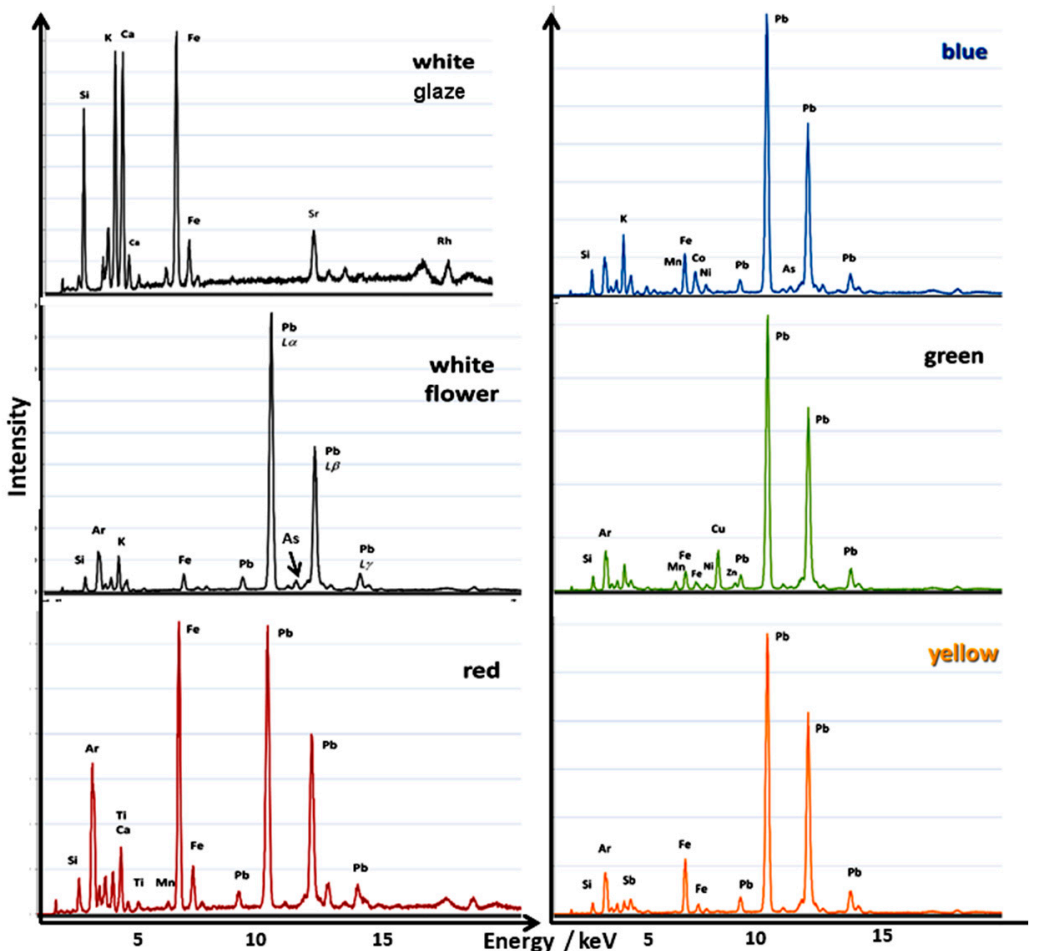

Figure 14. Representative portable XRF (pXRF) spectra recorded on the TH457 bottle for the glaze and different painted enamels.
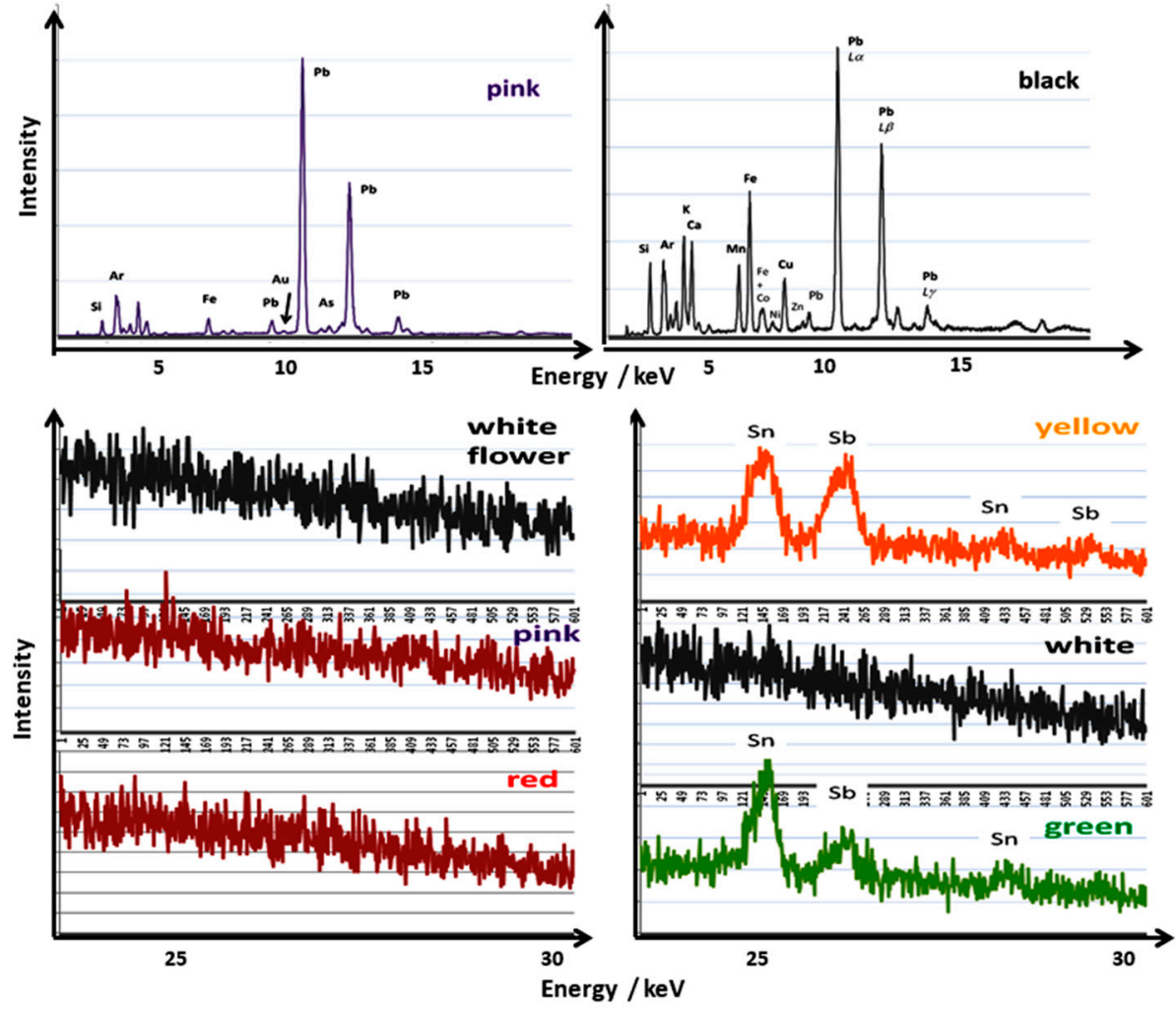

Figure 15. Representative pXRF spectra recorded on the TH457 bottle for pink and black enameled areas; bottom: zoom in on the energy window characteristics of $\mathrm{Sn}$ and $\mathrm{Sb}$ elements for different areas. 


\subsubsection{Red to Violet Colors}

The last important characteristic of the painted enameled porcelains analyzed was the presence of different methods for obtaining red-related colors. The use of hematite or gold nanoparticles was identified in the painted enamels to obtain red, orange to pink/purple hues (Table 2). In only two artifacts, the TH457 bottle (Figures 3 and 7A, white-pink and red) and R1175 plates (Figures 2 and 8A(c,d), orange and red; and Figure $8 \mathrm{~B}(\mathrm{c})$, red), the use of both methods was observed. Hematite has a well-defined Raman signature, with a strong (ca. 1305-1310 $\mathrm{cm}^{-1}$ ) mode (resonance signal of magnon mode under green laser excitation) and narrow peaks between 200 and $600 \mathrm{~cm}^{-1}[62,63]$ (see e.g., Figure $6 \mathrm{D}\left(\mathrm{b}, \mathrm{b}^{\prime}, \mathrm{b}^{\prime \prime}\right)$, Figure $7 \mathrm{~A}$, Figure $8 \mathrm{~A}(\mathrm{c}), \mathrm{B}(\mathrm{c})$ and Figure $\left.12 \mathrm{C}\left(\mathrm{b}, \mathrm{b}^{\prime}\right)\right)$. The magnon mode is very sensitive to the particle size of hematite [63] and the oxygen stoichiometry [62], with small particles giving an orange-red color [29]. Broadening of hematite peaks indicates a partial substitution of iron with other elements, possibly Ti and $\mathrm{Al}$ coming from the iron sources [29].

A specific Raman feature referred to the use of gold nanoparticles dispersed in the glassy matrix of the enamel (this type of enamel is at the origin of the label "Famille rose" [15,19], with a characteristic broad fluorescence background peaking at $\sim 500-600 \mathrm{~cm}^{-1}$ under a green laser, corresponding to $\sim 500 \mathrm{~nm}$ on the absolute scale [14,18]; see Figure 6C(c) (R1041), Figure 7A (TH457), Figure 8A(d) (R1175), Figure 9B(c) (SN284), Figure 10A(a, $\left.a^{\prime}\right), B(d)$ (TH487), Figure 12C(a) (F1429C) and Figure 13C(a) (F1341C)). This method was first experimented with in 17th-century France by the glassmaker Bernard Perrot and then some years later by Johann Kunckel in Germany and certainly by others in Italy before $[16,18,64-67]$. The presence of gold was also confirmed by pXRF analysis (see arrow on Figure 15-pink, in which the small $\mathrm{Au} \mathrm{L}_{\alpha}$ peak is obvious), with a hardly visible peak well-identified by data fitting. In addition, it is important to note that a very small band characteristic of the As-O stretching band at ca. $820 \mathrm{~cm}^{-1}$ could be detected along with the fluorescence background characteristic of the use of colloidal gold (seen clearly in Figure 10A(a,a') (TH487) and less intensely in Figure 9B(c) (SN284) and Figure 13C(a) (F1341C)). This band corresponds to the use of Perrot's preparation route for obtaining the colloidal gold precipitate using an arsenic salt, which is different from that of Kunckel, who made use of a tin salt instead [16]. Similar Raman signatures were observed for painted Chinese enameled wares of the same period [14] as well as on French enameled watches [18].

\subsection{Glassy Matrix}

Raman spectra of the glazes/painted overglaze enamels showed the characteristic signature of glassy silicates, which basically include $\mathrm{Si}-\mathrm{O}$ bending and stretching bands in the range $\sim 500$ and $\sim 1000 \mathrm{~cm}^{-1}$, respectively. A comparison of the Si-O stretching band components and the area ratio of the $\mathrm{Si}-\mathrm{O}$ bending/stretching band has proved to be very efficient for the compositional classification of different glass/glaze/enamel types based on experimental Raman data obtained for a great deal of ancient glassy objects [68-71] as well as on Density Functional Theory calculations [72]. The glazes were aluminosilicate glazes, with the Si-O stretching bands varying between ca. 900 and $1200 \mathrm{~cm}^{-1}$. The painted enamels analyzed displayed a broad and strong band varying between $\sim 920$ and $1070 \mathrm{~cm}^{-1}$ with various shoulders/components, indicating mainly lead-based compositions [69-71], as observed for soft-paste porcelains [17] and enameled metalware [14,18]. In some of the spectra, the intensity of the $\mathrm{Si}-\mathrm{O}$ bending modes near $500 \mathrm{~cm}^{-1}$ appeared to be equal to or weaker than that of the stretching modes at $950-1050 \mathrm{~cm}^{-1}$ (see e.g., Figure $6 \mathrm{~A}(\mathrm{c}), \mathrm{C}(\mathrm{a})$, Figure $10 \mathrm{~B}(\mathrm{~b})$ and Figure $13 \mathrm{~B}\left(\mathrm{a}^{\prime}, \mathrm{a}^{\prime \prime}\right)$ ). This indicates a polymerization ratio close to less than 1 , according to firing at temperatures inferior to 900-1000 ${ }^{\circ} \mathrm{C}[68,71]$. The painted enamels can be further classified into three main glass types (Table 3) based on representative glass (and glaze) types $[12,13,16,68,69]$ and previous studies conducted on Chinese cloisonné and painted enamels [10,14,73-76]: (i) lead-rich glass with the strongest component at ca. 920 to $1020 \mathrm{~cm}^{-1}$ (Type I); (ii) lead (earth) alkali glass with the strongest component at ca. 1030 to $1060 \mathrm{~cm}^{-1}$ (Type IIa), with rather similar-intensity components at ca. 980 and $1040 \mathrm{~cm}^{-1}$ (Type Ilb); and (iii) lead (earth) alkali glass with the strongest component at ca. $1070 \mathrm{~cm}^{-1}$ (Type III). Some of the yellow, green and black enamels belonged to the lead-rich type of glass, with their strongest component 
at low wavenumbers, which indicates a low degree of polymerization and firing at low temperatures (the addition of Naples yellow increases the lead content). Most of the painted enamels (white and blue) belonged to the lead alkali type of glass (the addition of smalt increases the potassium content), with their strongest component shifted to higher wavenumbers (up to ca. $1060 \mathrm{~cm}^{-1}$ ) accompanied by a similar low wavenumber component to the lead-rich glass. The glass compositions of the painted enamels did not show much variety, indicating a limited number of firings over the transparent glaze.

Table 3. $\mathrm{SiO}_{4}$ stretching components of the glassy matrix of the painted enamels analyzed (strongest; shoulder/weak) and comparison with Chinese enameled metalware (Lead alkali glass: L-a; $\overline{\text { Lead-rich }}$ glass: L-rich).

\begin{tabular}{|c|c|c|c|c|c|}
\hline Artifact & $\begin{array}{l}\text { Si-O Stretching } \\
\text { Components } \\
\left(\mathrm{cm}^{-1}\right)\end{array}$ & Color & Glass Type & $\begin{array}{l}\text { Observed in } \\
\text { Cloisonné } \\
\text { Metalware [14] }\end{array}$ & $\begin{array}{l}\text { Observed in } \\
\text { Painted } \\
\text { Metalware [14] }\end{array}$ \\
\hline F1371C & $\underline{1025}, 1130$ & White, blue & L-a IIa & \multirow{3}{*}{ Blue and white } & \multirow{3}{*}{$\begin{array}{c}\text { Not } \\
\text { observed } \\
\text { except } \\
\text { F1440C }\end{array}$} \\
\hline R1048 & $\begin{array}{c}980, \frac{1040}{975}, \underline{1040} \\
\underline{1075}\end{array}$ & $\begin{array}{c}\text { White } \\
\text { Blue } \\
\text { Black, yellow, red }\end{array}$ & $\begin{array}{l}\text { L-a IIa } \\
\text { L-a IIa } \\
\text { L-a III }\end{array}$ & & \\
\hline R1056 & $980, \underline{1035}$ & White & L-a IIa & & \\
\hline TH457 & $\begin{array}{c}985,1130 \\
\underline{985} \\
\underline{1070}\end{array}$ & $\begin{array}{c}\text { White pink } \\
\text { Yellow } \\
\text { Dark yellow, red, } \\
\text { blue }\end{array}$ & $\begin{array}{l}\text { L-rich I } \\
\text { L-rich I } \\
\text { L-a III }\end{array}$ & $\begin{array}{l}\text { Yellow and } \\
\text { black } \\
\text { Green-yellow }\end{array}$ & $\begin{array}{c}\text { Yellow and } \\
\text { turquoise } \\
\text { yellow and green }\end{array}$ \\
\hline R1175 & $\begin{array}{c}985, \underline{1040} \\
\frac{975}{985,1040} \\
905, \frac{970, \underline{1035}, 1120}{\underline{97}}\end{array}$ & $\begin{array}{c}\text { Blue } \\
\text { Yellow } \\
\text { Black } \\
\text { Green, orange, } \\
\text { red }\end{array}$ & $\begin{array}{l}\text { L-a IIa } \\
\text { L-rich I } \\
\text { L-a IIb } \\
\text { L-a IIa }\end{array}$ & $\begin{array}{l}\text { See above } \\
\text { See above } \\
\text { Green }\end{array}$ & Green \\
\hline TH487 & $\begin{array}{c}975, \frac{1050}{970, \frac{1045}{1140}} \\
920, \frac{1140}{915,}, \frac{971,1037}{} \\
\end{array}$ & $\begin{array}{c}\text { Blue } \\
\text { Yellow } \\
\text { Black } \\
\text { Green, red }\end{array}$ & $\begin{array}{l}\text { L-a IIa } \\
\text { L-a IIa } \\
\text { L-rich I } \\
\text { L-a IIb }\end{array}$ & \multirow{6}{*}{ See above } & \\
\hline R1045 & $\underline{975,1035}$ & Blue, white & L-a IIb & & \\
\hline R1041 & $980, \underline{1050}$ & Blue, pink & L-a IIa & & \\
\hline R1006 & $\underline{1015}$ & $\begin{array}{l}\text { Yellow } \\
\text { Black }\end{array}$ & $\begin{array}{l}\text { L-rich I } \\
\text { L-rich I }\end{array}$ & & \\
\hline SN284 & $980, \underline{1060}$ & Yellow, red, pink & L-a IIa & & \\
\hline R1135 & $\underline{1020}$ & Green, blue, red & L-rich I & & \\
\hline F1341C & $\begin{array}{l}\frac{970,1035}{980,1030} \\
\underline{1040,1090}\end{array}$ & $\begin{array}{l}\text { White, blue } \\
\text { Green } \\
\text { Red }\end{array}$ & $\begin{array}{l}\text { L-a IIb } \\
\text { L-a IIb } \\
\text { L-a IIa }\end{array}$ & & \\
\hline F1429C & $\begin{array}{c}980, \underline{1030}, 1140 \\
970, \underline{1020} \\
900, \underline{975}, \underline{1010}, 1130 \\
900,975, \underline{1010}, 1125\end{array}$ & $\begin{array}{l}\text { White, blue } \\
\text { Light pink } \\
\text { Yellow } \\
\text { Green }\end{array}$ & $\begin{array}{l}\text { L-a IIa } \\
\text { L-a IIa } \\
\text { L-rich I } \\
\text { L-a IIb }\end{array}$ & & \\
\hline
\end{tabular}

\subsection{XRF Analysis}

One of the porcelain artifacts, the TH457 bottle, was analyzed by pXRF. This artifact exhibits the most sophisticated decor, and its shape is well-suited for XRF analysis using a portable instrument since the analyzed area must be roughly perpendicular to the instrument [18]. Additionally, the distance between the instrument and the artifact must be small $(\sim 10 \mathrm{~mm})$, and flat areas are required. Figures 14 and 15 show the representative XRF spectra recorded on the white glaze and the different 
overglaze enamels (white, blue, green, red, yellow, pink and black) in the 1-22 keV range, where most of the peaks characteristic of major and minor elements were observed. Figure 15 shows details of the 24-30 keV range, where peaks of tin and antimony elements could be compared visually.

As expected for porcelains, the glaze showed elements characteristic of a glassy aluminosilicate porcelain glaze fired at a high temperature [1-3,28-31] with high levels of potassium, calcium and silicon (Table 4). Significant iron content was also obvious in the (colorless) glaze. The high whiteness of the glaze, in association with some iron impurities, demonstrated a firing process under a reducing atmosphere that imposed $\mathrm{Fe}^{2+}$ speciation. These ions lead to a weak blue coloration, reinforcing the "whiteness" of the glaze for human eyes. Strontium, an impurity of calcium, was detected at a significant level. Light elements such as sodium could not be detected due to their low atomic number. All overglaze enamels were lead-rich: all the $\mathrm{L}_{\alpha}, \mathrm{L}_{\alpha}, \mathrm{L}_{\alpha}$ XRF transitions of the lead element were clearly observed. A comparison between the relative intensity of lead and potassium or calcium peaks indicated the lower content of lead in the black enamels.

Table 4. The glaze and overglaze painted enamels analyzed by pXRF. (Major-minor-traces).

\begin{tabular}{ll}
\hline Glaze & Elements \\
\hline White & $\mathrm{Si}, \mathbf{K}, \mathbf{C a}, \mathbf{F e}-\mathrm{Sr}$ \\
\hline Overglaze enamel & \\
\hline Blue & $\mathrm{Si}, \mathbf{P b}-\mathrm{K}, \mathrm{Co}, \mathrm{Fe}, \mathrm{As}-\mathrm{Ni}, \mathrm{Mn}$ \\
\hline White & $\mathrm{Si}, \mathbf{P b}-\mathrm{K}, \mathrm{Fe}, \mathrm{Ca}, \mathrm{As}-\mathrm{Ni}$ \\
\hline Green & $\mathrm{Si}, \mathbf{P b}-\mathrm{Cu}, \mathrm{Fe}, \mathrm{K}, \mathrm{Ca}, \mathrm{Sn}, \mathrm{Zn}-\mathrm{Mn}, \mathrm{Ni}, \mathrm{C} o$ ?) \\
\hline Yellow & $\mathrm{Si}, \mathbf{P b}-\mathrm{K}, \mathrm{Sb}, \mathrm{Fe}, \mathrm{Sn}-\mathrm{Ni}$ \\
\hline Red & $\mathrm{Si}, \mathbf{F e}, \mathbf{P b}-\mathrm{K}, \mathrm{Ca}, \mathrm{Ti}-\mathrm{Mn}$ \\
\hline Pink & $\mathrm{Si}, \mathbf{P b}-\mathrm{K}, \mathrm{Ca}, \mathrm{Fe}, \mathrm{As}-A u, N i$ \\
\hline Black & $\mathrm{Si}, \mathbf{K}, \mathbf{C a}, \mathbf{P b}, \mathrm{Fe}-\mathrm{Mn}, \mathrm{Co}, \mathrm{Cu}-N i, \mathrm{Zn}$ \\
\hline
\end{tabular}

The XRF spectrum of the blue overglaze enamel showed strong lead peaks; pronounced arsenic, iron and cobalt peaks; and weak manganese and nickel peaks. Arsenic was also observed in the white overglaze enamel (flower decor) as well as in the pink one. Arsenic content is visually detected by the small $A s \mathrm{~K}_{\beta}$ peak just before the $\mathrm{Pb} \mathrm{L}_{\alpha}$ one, the As $\mathrm{K}_{\alpha}$ peak being at the same position as the strong $\mathrm{Pb} \mathrm{L}_{\alpha}$ one. Confirmation was carried out with the software fitting. Note the high intensity of the potassium peak in blue, according to the use of smalt. The presence of nickel and manganese was due to the impurities found in the cobalt ore used (Table 4). The intensity of the iron peak was rather similar for all overglaze enamels. The presence of manganese was thus consistent with the implication that Asian and European cobalt ingredients were mixed. The detection of arsenic was also significant in relation to the type of the cobalt ore. The red overglaze enamel displayed significant iron peaks, in accordance with the Raman identification of hematite (Figure 7A). Minor amounts of titanium and traces of manganese were also observed, possibly coming from the hematite source. The pink overglaze enamel displayed minor amounts of iron, also indicating the use of hematite. In addition to that, the detection of gold traces was significant, confirming the use of colloidal gold for obtaining the desired hue. The presence of arsenic was also in accordance with the use of Perrot's technique.

The yellow overglaze enamel showed distinct peaks of iron together with minor amounts of antimony and tin, indicating the use of a complex $(\mathrm{Fe}) \mathrm{Sb}$-rich Naples yellow lead pyrochlore pigment (see Section 3.2). A similar type of this pigment also seemed to have been used for the green overglaze enamel, with a higher amount of tin and some zinc. Antimony was detected in the low-energy range, but a magnification of the 24-30 keV range (Figure 15) showed the variable content of tin and antimony elements more clearly. The green enamel additionally included copper, which contributes to color formation, together with manganese, nickel and zinc. It was difficult to see if cobalt was also present. 
Iron was clearly observed in the black overglaze enameled areas (Table 4). Black enamel was obviously obtained with a mixture of iron and manganese in the presence of copper (and cobalt?), according to the Raman identification of manganese-rich oxide (spinels) (see e.g., Figure 6B(dd') (R1048), Figure 8A(e) (R1175), Figure 9A(e, $\left.\mathrm{e}^{\prime}, \mathrm{e}^{\prime \prime}\right)(\mathrm{R} 1006)$ and Figure 10B(c', $\left.\left.\mathrm{c}^{\prime \prime}\right)(\mathrm{TH} 487)\right)$. It is important to note that relative intensities of lead and silicon elements measured on the black lines were intermediate between those measured on other overglaze enamels and that of the glaze. This is due to the limited thickness of the black lines: the XRF spectrum (Figure 15) both displayed the contribution of the black line plus those of adjacent areas, the glaze on one side and the colored overglaze on the other side. All the data obtained by pXRF were in perfect agreement with the Raman data.

\section{Comparison with Painted Enameled Metalware}

The characteristics of porcelain and metal enameling were expected to be very much linked to each other in terms of the pigments/opacifiers used and the firing conditions employed. At the end of the 17th and early 18th century in China, enameling workshops both in charge of metal and porcelain enameling were established in the Forbidden City by the Jesuit mission to satisfy the demand of the Kangxi Emperor [4-8]. These workshops are considered to have been in close contact with each other [27]. The present study has shown that the material characteristics and production technology of 18th-century Chinese painted enameled porcelains and the painted enameled metalware of the same period are very similar. Pigments/opacifiers of European origin, such as Naples yellow lead pyrochlore pigment (yellow to green enamels), colloidal gold (red, orange and pink enamels) and lead arsenate phases (white and blue enamels) as well as similar lead-based glass compositions were identified in both of the enameled ware types. However, with the present state of knowledge, some differences can be noted on the diffusion of these new technologies in China. Tables 5 and 6 chronologically compare the appearance of European technologies for blue, white, yellow/green and red/pink enamels of porcelain and metalware, respectively.

Table 5. Chronological summary of the innovative technologies evidenced in Chinese enameled porcelains (A: arsenic-based apatite).

\begin{tabular}{|c|c|c|c|c|}
\hline $\begin{array}{c}\text { Period (Assignment Based } \\
\text { on Decor Style) }\end{array}$ & Porcelain & $\begin{array}{c}\text { Specific } \\
\text { Technologies }\end{array}$ & Remarks & Refs \\
\hline \multirow{5}{*}{$\begin{array}{l}\text { Final period of Kangxi reign } \\
\qquad(<1722)\end{array}$} & $\begin{array}{l}\text { G1710 } \\
\text { vase }\end{array}$ & $\frac{\text { Ming blue }}{\text { Sn-N.y.(s) }}$ & $\begin{array}{c}\text { "Biyu tang zhi" mark } \\
\text { Famille verte/Famille noire } \\
\text { J.p.k. }\end{array}$ & [12] \\
\hline & $\begin{array}{l}\text { G822 } \\
\text { dish }\end{array}$ & $\begin{array}{l}\text { Sn-N.y. (s) } \\
\quad \underline{H-r e d}\end{array}$ & $\begin{array}{c}\text { "Da Qing Kangxi nian zhi" } \\
\text { mark } \\
\text { Famille verte } \\
\text { J.I.F }\end{array}$ & [12] \\
\hline & $\begin{array}{l}\text { G5696 } \\
\text { bowl }\end{array}$ & $\frac{\frac{\text { Ming blue }}{\text { H-red }}}{\text { Sn/Sb-N.y.(s) }}$ & $\begin{array}{c}\text { "Da Qing Kangxi nian zhi" } \\
\text { mark } \\
\text { doucai } \\
\text { J.I.F }\end{array}$ & [12] \\
\hline & $\begin{array}{l}\text { G5250 } \\
\text { bowl }\end{array}$ & $\begin{array}{c}\text { As-blue; Ming blue } \\
\text { Sb-N.y.; Sn-N.y. } \\
\text { Au }^{\circ} \\
\text { Cassiterite? }\end{array}$ & $\begin{array}{c}\text { "Kangxi yu zhi" mark } \\
\text { huafalang } \\
\text { P.w. }\end{array}$ & {$[12,17]$} \\
\hline & $\begin{array}{c}\text { G3361 } \\
\text { water dropper }\end{array}$ & $\begin{array}{l}\text { As-blue } \\
\text { As-white } \\
\text { Sn-N.y. } \\
\mathrm{Au}^{\circ}\end{array}$ & $\begin{array}{l}\text { "Da Qing Kangxi nian zhi" } \\
\text { mark } \\
\text { Famille rose } \\
\text { J.I.F. }\end{array}$ & [12] \\
\hline
\end{tabular}


Table 5. Cont

\begin{tabular}{|c|c|c|c|c|}
\hline $\begin{array}{c}\text { Period (Assignment Based } \\
\text { on Decor Style) }\end{array}$ & Porcelain & $\begin{array}{c}\text { Specific } \\
\text { Technologies }\end{array}$ & Remarks & Refs \\
\hline & $\begin{array}{l}\text { R1006 } \\
\text { cup }\end{array}$ & $\frac{\text { Ming blue }}{\text { Sn-N.y. }}$ & & This work \\
\hline \multirow{10}{*}{ Yongzheng reign (1723-1735) } & $\begin{array}{l}\text { R1056 } \\
\text { dish }\end{array}$ & $\begin{array}{l}\text { As-white } \\
\text { Sn-N.y. }\end{array}$ & & This work \\
\hline & $\begin{array}{l}\text { R1041 } \\
\text { cup }\end{array}$ & $\begin{array}{c}\text { As-blue } \\
\mathrm{Au}^{\circ}\end{array}$ & & This work \\
\hline & MG4806 bowl & $\frac{\text { Ming blue }}{\text { Sb-N.y. (s) }}$ & $\begin{array}{l}\text { "Yongzheng yu zhi" mark } \\
\text { huafalang/yangcai } \\
\text { J.I.F. }\end{array}$ & [12] \\
\hline & $\begin{array}{c}\text { MG913 } \\
\text { bow1 }\end{array}$ & $\begin{array}{l}\text { As-blue } \\
\text { As-white } \\
\text { Sn-N.y. (s) } \\
\text { H-red } \\
\end{array}$ & $\begin{array}{c}\text { "Yongzheng yu zhi" mark } \\
\text { huafalang/yangcai } \\
\text { J.I.F.(?) }\end{array}$ & [12] \\
\hline & MG7368 bowl & $\begin{array}{l}\text { Ming blue } \\
\text { N.y. (s) } \\
\underline{\text { H-red }}\end{array}$ & $\begin{array}{c}\text { "Da Qing Yongzheng nian zhi" } \\
\text { mark, doucai } \\
\text { J.p.k. }\end{array}$ & [12] \\
\hline & $\begin{array}{c}\text { R1175 } \\
\text { dish }\end{array}$ & $\begin{array}{c}\text { As-blue (A) } \\
\mathrm{CaF}_{2}(?), \mathrm{Au}^{\circ} \\
\text { Sn/Sb-N.y., H-red }\end{array}$ & & This work \\
\hline & $\begin{array}{c}\text { TH487 } \\
\text { dish }\end{array}$ & $\begin{array}{l}\text { As-blue } \\
\text { Sn/Sb-N.y. } \\
\mathrm{Au}^{\circ}\end{array}$ & & This work \\
\hline & $\begin{array}{c}\text { F1341C } \\
\text { bottle }\end{array}$ & $\begin{array}{c}\text { As-blue } \\
\text { Sn-N.y. } \\
\text { Au }^{\circ} ; \underline{\text { H-red }}\end{array}$ & & This work \\
\hline & $\begin{array}{l}\text { SN284 } \\
\text { milk pot }\end{array}$ & $\begin{array}{l}\text { As-blue (A) } \\
\text { Sn-N.y. } \\
\mathrm{Au}^{\circ}\end{array}$ & & This work \\
\hline & $\begin{array}{l}\text { SN284 } \\
\text { cup }\end{array}$ & $\begin{array}{l}\text { Sn-N.y. } \\
\mathrm{Au}^{\circ}\end{array}$ & & This work \\
\hline \multirow{7}{*}{ Qianlong reign (>1735-1750) } & $\begin{array}{l}\text { Shard } \\
\text { bowl }\end{array}$ & $\begin{array}{c}\text { As-blue } \\
\text { As-white } \\
\underline{H-r e d} \\
\text { Sn-N.y. (yellow) } \\
\text { Sb-N.y. (green) }\end{array}$ & From Palace excavation & [13] \\
\hline & $\begin{array}{l}\text { R1045 } \\
\text { cup }\end{array}$ & As-blue & & This work \\
\hline & $\begin{array}{c}\text { F1429C } \\
\text { teapot }\end{array}$ & $\begin{array}{l}\text { As-blue(A) } \\
\text { Sb-Sn-Y.y. } \\
\mathrm{Au}^{\circ}\end{array}$ & & This work \\
\hline & $\begin{array}{l}\text { TH457 } \\
\text { bottle }\end{array}$ & $\begin{array}{l}\frac{\text { Ming blue }}{\text { Sn-N.y. }} \\
\text { Sb-Sn-N.y. } \\
\mathrm{Au}^{\circ}, \underline{\text { H-red }}\end{array}$ & & This work \\
\hline & $\begin{array}{c}\text { F1371C } \\
\text { bottle }\end{array}$ & $\begin{array}{l}\text { As-white } \\
\text { As-blue (A) } \\
\text { Sn-N.y. }\end{array}$ & & This work \\
\hline & $\begin{array}{l}\text { R1025 } \\
\text { dish }\end{array}$ & $\begin{array}{l}\text { As-blue (A) } \\
\mathrm{Au}^{\circ}\end{array}$ & & This work \\
\hline & $\begin{array}{l}\text { R1048 } \\
\text { cup }\end{array}$ & $\begin{array}{l}\text { As-white, As-blue } \\
\text { Sn-N.y., } \underline{H-r e d}\end{array}$ & & This work \\
\hline
\end{tabular}


Table 5. Cont.

\begin{tabular}{|c|c|c|c|c|c|}
\hline $\begin{array}{l}\text { Period (Assignment Based } \\
\text { on Decor Style) }\end{array}$ & Porcelain & \multicolumn{2}{|c|}{$\begin{array}{c}\text { Specific } \\
\text { Technologies }\end{array}$} & Remarks & Refs \\
\hline \multirow{2}{*}{ Qianlong reign (1750-1800) } & MG3668 teapot & \multicolumn{2}{|c|}{$\begin{array}{c}\text { As-blue, } \mathrm{Au}^{\circ} \\
\text { As-white } \\
\text { Sn-Sb-N.y. }\end{array}$} & Yixing p.k. & [12] \\
\hline & MG9604 teapot & \multicolumn{2}{|c|}{$\begin{array}{l}\text { As-blue } \\
\text { As-white } \\
\text { Sb-N.y. }\end{array}$} & Yixing p.k. & {$[12,17]$} \\
\hline \multicolumn{6}{|c|}{$\begin{array}{l}\text { P.w.: palace workshop; J.I.F.: Jingdezhen Imperial Factory; J.p.k.: Jingdezhen private kiln; As-blue: } \\
\text { European cobalt; Sb-N.y.: Sb-rich Naples yellow; Sn-N.y.: Sn-rich Naples yellow; s: small } \\
\text { intensity; ancient Ming technology: Asian blue; hematite red; MGxxx: Musée national des arts asiatiques-Guimet } \\
\text { inventory number. }\end{array}$} \\
\hline Period & \multirow[t]{2}{*}{ Painted } & \multirow[t]{2}{*}{$\begin{array}{c}\text { Specific } \\
\text { Technologies }\end{array}$} & Cloisonné & $\begin{array}{c}\text { Specific } \\
\text { Technologies }\end{array}$ & Remarks \\
\hline $\begin{array}{l}\text { Final period } \\
\text { of Kangxi } \\
\text { reign }(<1722)\end{array}$ & & & F1448C & $\begin{array}{l}\text { Sb-Sn-N.y. } \\
\text { Sn-N.y. } \\
\text { Cassiterite } \\
\mathrm{Au}^{\circ}\end{array}$ & $\begin{array}{c}\text { Palace } \\
\text { workshop? }\end{array}$ \\
\hline $\begin{array}{l}\text { Qianlong } \\
\text { reign } \\
(1735-1750)\end{array}$ & R957 & $\begin{array}{c}\text { As-white } \\
\text { As-blue } \\
\text { As-blue (A) }\end{array}$ & & & Guangzhou \\
\hline \multirow{2}{*}{$\begin{array}{l}\text { Qianlong } \\
\text { reign } \\
(1750-1775)\end{array}$} & \multirow[b]{2}{*}{ F1440C } & Sn-N.y. & F1735C & $\begin{array}{l}\text { Sb-Sn-N.y. } \\
\text { Sn-N.y. }\end{array}$ & Qianlong mark \\
\hline & & $\begin{array}{c}\text { As-blue } \\
\text { Sb-N.y. } \\
\text { Sn-N.y. } \\
\mathrm{Au}^{\circ}\end{array}$ & & & \\
\hline \multirow{5}{*}{$\begin{array}{c}\text { Qianlong } \\
\text { reign } \\
(<1775-1800)\end{array}$} & R958 & $\begin{array}{c}\text { As-blue (A) } \\
\text { As-white } \\
\text { Sn-N.y. } \\
\mathrm{Au}^{\circ}\end{array}$ & & & Guangzhou \\
\hline & R975 & $\begin{array}{c}\text { As-blue } \\
\text { Sb-Sn-N.y. } \\
\mathrm{Au}^{\circ} ?\end{array}$ & & & Guangzhou \\
\hline & & & F1501 & $\begin{array}{l}\text { As-blue } \\
\text { Sb-Sn-N.y. } \\
\text { Sn-N.y. } \\
\mathrm{Au}^{\circ} ?\end{array}$ & $\begin{array}{c}\text { Palace } \\
\text { workshop }\end{array}$ \\
\hline & & & F1467.1/.2 & $\begin{array}{l}\text { Sb-N.y. } \\
\text { Sn-N.y. } \\
\mathrm{Au}^{\circ}\end{array}$ & \\
\hline & $\mathrm{F} 1467.1 / .2$ & $\begin{array}{l}\text { As-blue } \\
\text { Sb-N.y. } \\
\text { Sn-N.y. } \\
\text { Cassiterite }\end{array}$ & & & Qianlong mark \\
\hline Qianlong reign (>1800)? & F1698C & $\begin{array}{l}\text { As-blue } \\
\text { Sn-N.y. }\end{array}$ & & & Guangzhou \\
\hline
\end{tabular}

Regarding the blue overglaze enamels studied so far, the change from Ming blue (made with Asian cobalt ores) to As-rich blue (pure European cobalt ores or mixing with Asian ones) is suggested 
for the artifacts assigned to the end of the Kangxi reign on the basis of the decor style. It seems that both types of blue were used in the MG5250 "Imperial" bowl [12]. This bowl also exhibited the Raman spectrum characteristic of the use of colloidal-gold-based (Famille rose) enamel. Naples yellow pyrochlore, tin-rich, was the first European technology imported, but the addition of antimony was expected in the MG5696 "Imperial" bowl [12]. A weak signal of cassiterite was even detected in a similar shard [17]. It can be also noted that the MG5250 bowl is assigned to have been made at the palace workshop; the same innovative technology of enameling was observed for the MG3361 pencil water dropper assigned to have been made at the Jingdezhen Imperial Factory [12]. This indicates a very rapid transfer of technology from the palace workshop managed under the Jesuits' guidance to the imperial kilns at Jingdezhen. The Sn-rich Naples yellow (in yellow and green enamels) appears to have been used more frequently than the Sb-rich homologue up to the mid-18th century. The addition of Naples yellow increased the lead content. The use of cassiterite seems be exceptional, and its use must be confirmed by an examination of shard sections of similar artifacts.

It is worth mentioning that cassiterite was identified in the painted enamels of the metalware, as an opacifier, for a Kangxi cloisonné metalware piece and the exceptional painted and cloisonné Qianlong ewers from the French emperor's collection. Regarding enameled porcelain, Sn- and Sb-rich Naples yellow pyrochlores appear to have been used since the final period of the Kangxi reign. The same conclusions can be drawn for the use of colloidal gold for red to pink colors. By comparison, it appears that almost all enameled metalware was prepared with the European technologies, including As-rich cobalt, although enamel traditional recipes such as Ming blue were used simultaneously with new ones (Ming blue was used for underglaze decor). More artifacts must be analyzed to confirm this point.

\section{Conclusions}

The present on-site Raman study of intact Chinese painted enameled porcelains from the 18th century sheds light on the materials (pigments/opacifiers, colorants, glass types of glazes/enamels and body phases) and the technology used during their production. The study also provides a comparative approach for the technical aspects of painted enameled porcelains and contemporaneous enameled metalware regarding the different reigns of the Qing dynasty. The use of the same on-site analytical protocol for these artifact groups is advantageous for comparing the data obtained. The outcomes are significant in terms of the know-how transfer (materials/techniques) from Europe to China by the Jesuit mission at the end of the 17th century.

From the (limited) number of objects studied, it appears that the first innovations were the different types of Naples yellow lead pyrochlore pigments and then the use of European cobalt during the later years of the Kangxi reign for enameled porcelains. Cassiterite appeared first during the same period in certain cloisonné enamel wares. The detection of cassiterite traces in a Kangxi enamel is assigned to (the effect of) the use of Sn-rich Naples yellow that induced precipitation of cassiterite. Its addition to adjust the hue is also possible. More artifact studies are needed to clarify this point. Yongzheng enameled objects made use of European recipes for blue, yellow and rose; the opacification with different As phases was identified. Unfortunately, only one metalware piece from the Yongzheng period has been studied [14]. Studies of a larger number of objects are required, in particular to study the technology transfer from the Imperial Palace to the Jingdezhen imperial kilns and to private kilns in Jingdezhen or Guangzhou [27] to really have a statistical view of the number of porcelains on which the lead-based enamels were deposited directly on the body and not on the glazed body [77].

Author Contributions: Conceptualization, P.C. and B.Z.; methodology, P.C.; validation, P.C. and B.K.; investigation, P.C.; resources, B.Z., J.-B.C., Y.Y. and V.D.; writing—original draft preparation, P.C.; writing—review and editing, P.C. and B.K.; funding acquisition, P.C. and B.Z. All authors have read and agreed to the published version of the manuscript.

Funding: This research was funded by the French Agence Nationale de la Recherche ANR EnamelFC project-19-CE27-0019-02 and by the Partenariat 'Hubert Curien' PHC-Cai Yuanpei Campus France-China cooperative program. 
Acknowledgments: M. Gironda from ELIO, XGLab/Bruker is kindly acknowledged for recording the XRF data. C. Gougeon from the Louvre Museum and S. Paronetto from Fontainebleau Castle are acknowledged for their help in the preparation of the measurement campaigns. J. Defretin is acknowledged for providing historical information on some artifacts. Yong Lei and Huawen Liu from the Palace Museum, Department of Analysis and Conservation and Professor Ludovic Bellot-Gurlet from MONARIS (Laboratoire de la MOlécule au Nano-objet: Réactivité, Interaction \& Spectroscopies) are kindly acknowledged for many discussions. This work has been conducted under the framework of the Laboratoire International Associé CNRS-Palace Museum TrEnamel and Campus France PHC-Cai Yuanpei programs.

Conflicts of Interest: The authors declare no conflict of interest.

\section{References}

1. Montanari, R.; Alberghina, M.F.; Casanova Municchia, A.; Massa, E.; Pelagotti, A.; Pelosi, C.; Schiavone, S.; Sodo, A. A polychrome Mukozuke (1624-1644) porcelain offers a new hypothesis on the introduction of European enameling technology in Japan. J. Cult. Herit. 2018, 32, 232-237. [CrossRef]

2. Montanari, R.; Murakami, N.; Alberghina, M.F.; Pelosi, C.; Schiavone, S. The Origin of overglaze-blue enameling in Japan: New discoveries and a reassessment. J. Cult. Herit. 2019, 37, 94-102. [CrossRef]

3. Montanari, R.; Murakami, N.; Colomban, P.; Alberghina, M.F.; Pelosi, C.; Schiavone, S. European Ceramic technology in the Far East: Enamels and pigments in Japanese art from the 16th to the 20th century and their reverse influence on China. Herit. Sci. 2020, 8, 48. [CrossRef]

4. Shih, C.F. Evidence of East-West exchange in the eighteenth century: The establishment of painted enamel art at the Qing Court in the reign of Emperor Kangxi. Natl. Palace Mus. Res. Quaterly 2007, 24, 45-94.

5. Zhou, S.Z. Research on Painted Enamels Porcelain Ware from the Qing Court; Wenwu Chubanshe: Beijing, China, 2008.

6. Lili, F. La Céramique Chinoise; China Intercontinental Press: Beijing, China, 2011.

7. Xu, X.D. Europe-China-Europe: The Transmission of the Craft of Painted Enamel in the Seventeenth and Eighteenth Centuries. In Goods from the East, 1600-1800 Trading Eurasia; Berg, M., Ed.; Houndmills, Basingstoke, Palgrave Macmillan: Hampshire, UK, 2015; pp. 92-106.

8. Zhao, B.; Wang, G.; Biron, I.; Colomban, P.; Hilaire-Pérez, L. La circulation des techniques de l'émail entre la France et la Chine du XVIIème au XIXème siècle. Le CNRS en Chine Bulletin 2016, 21, 21-25. Available online: http://www.cnrs.fr/derci/IMG/pdf/cnrsenchine_21_fr_final_pour_le_site_cnrs.pdf (accessed on 23 July 2020).

9. Zhou, L.L. Discussion on Falangcai Enamels-and the Difference between Falangcai and Yangcai. Shangai Bowuguan Jikan 2000, 8, 210-226.

10. Kırmızı, B.; Colomban, P.; Quette, B. On-site analysis of Chinese Cloisonné enamels from fifteenth to nineteenth centuries. J. Raman Spectrosc. 2010, 41, 780-790.

11. Colomban, P.; Arberet, L.; Kırmız1, B. On-Site Raman Analysis of 17th and 18th Century Limoges Enamels: Implications on the European Cobalt Sources and the Technological Relationship between Limoges and Chinese Enamels. Ceram. Int. 2017, 43, 10158-10165. [CrossRef]

12. Colomban, P.; Zhang, Y.; Zhao, B. Non-invasive Raman analyses of huafalang and related porcelain wares. Searching for evidence for innovative pigment technologies. Ceram. Int. 2017, 43, 12079-12088. [CrossRef]

13. Colomban, P.; Ambrosi, F.; Ngo, A.-T.; Lu, T.-A.; Feng, X.-L.; Chen, S.; Choi, C.-L. Comparative analysis of wucai Chinese porcelains using mobile and fixed Raman microspectrometers. Ceram. Int. 2017, 43, 14244-14256. [CrossRef]

14. Colomban, P.; Kırmızı, B.; Zhao, B.; Clais, J.-B.; Yang, Y. Non-invasive on-site Raman study of pigments and glassy matrix of the 17th-18th century painted enamelled Chinese metal wares: Comparison with French enamelling technology. Coatings 2020, 10, 471. [CrossRef]

15. Giannini, R.; Freestone, I.C.; Shortland, A.J. European cobalt sources identified in the production of Chinese famille rose porcelain. J. Archaeol. Sci. 2017, 80, 27-36. [CrossRef]

16. Colomban, P.; Kırmızı, B. Non-invasive on-site Raman study of polychrome and white enamelled glass artefacts in imitation of porcelain assigned to Bernard Perrot and his followers. J. Raman Spectrosc. 2020, 51, 133-146. [CrossRef]

17. Colomban, P.; Lu, T.-A.; Milande, V. Non-invasive on-site Raman study of blue-decorated early soft-paste porcelain: The use of arsenic-rich (European) cobalt ores-Comparison with huafalang Chinese porcelains. Ceram. Int. 2018, 44, 9018-9026. [CrossRef] 
18. Colomban, P.; Kırmızı, B.; Gougeon, C.; Gironda, M.; Cardinal, C. Pigments and glassy matrix of the 17th-18th century enamelled French watches: A non-invasive on-site Raman and pXRF study. J. Cult. Herit. 2020. [CrossRef]

19. Kingery, W.D.; Vandiver, P.B. The Eighteenth-Century Change in Technology and Style from the Famille-Verte Palette to the Famille-Rose Palette. In Technology and Style; Kingery, W.D., Ed.; Ceramics and Civilization Serie; The American Ceramic Society: Colombus, OH, USA, 1986; Volume 2, pp. 363-381.

20. Colomban, P. On-site Raman study of artwork: Procedure and illustrative examples. J. Raman Spectrosc. 2018, 49, 921-934. [CrossRef]

21. Colomban, P. The on-site/remote Raman analysis with mobile instruments: A review of drawbacks and success in cultural heritage studies and other associated fields. J. Raman Spectrosc. 2012, 43, 1529-1535. [CrossRef]

22. Vandenabeele, P.; Edwards, H.G.M.; Jehlička, J. The role of mobile instrumentation in novel applications of Raman spectroscopy: Archaeometry, geosciences, and forensics. Chem. Soc. Rev. 2014, 43, 2628-2649. [CrossRef]

23. Madariaga, J.M. Analytical chemistry in the field of cultural heritage. Anal. Methods 2015, 7, 4848-4876. [CrossRef]

24. Simsek, G.; Unsalan, O.; Bayraktar, K.; Colomban, P. On-site pXRF analysis of glaze composition and colouring agents of "Iznik" tiles at Edirne mosques (15th and 16th-centuries). Ceram. Int. 2019, 45, 595-605. [CrossRef]

25. Defretin, J. La Datation de la Porcelaine "Coquille D'euf" D'exportation du Musée du Louvre, Mémoire, 2nd Cycle-Histoire de L'art Appliquée Aux Collections; Ecole du Louvre: Paris, France, 2020.

26. Howard, D.S. Chinese Armorial Porcelain; Heirlomm \& Howard Ltd.: London, UK, 2003; Volume 2, p. 155.

27. Tang, H. 'The Colours of Each Piece': Production and consumption of Chinese Enamelled Porcelain, c.1728-c.1780. Ph.D. Thesis, Warwick University, Warwick, UK, March 2017. Available online: http: //wrap.warwick.ac.uk/91791 (accessed on 26 June 2020).

28. Colomban, P.; Treppoz, F. Identification and differentiation of ancient and modern European porcelains by Raman macro and micro-spectroscopy. J. Raman Spectrosc. 2001, 32, 93-102. [CrossRef]

29. Colomban, P.; Sagon, G.; Faurel, X. Differentiation of antique ceramics from the Raman spectra of their coloured glazes and paintings. J. Raman Spectrosc. 2001, 32, 351-360. [CrossRef]

30. Carty, W.M.; Senapati, U. Porcelain-raw materials, processing, phase evolution, and mechanical behavior. J. Am. Ceram. Soc. 1998, 81, 3-20. [CrossRef]

31. Sciau, P.; Noé, L.; Colomban, P. Metal nanoparticles in contemporary potters' masterpieces: Lustre and red "pigeon blood" potteries as models to understand the ancient pottery. Ceram. Int. 2016, 42, 15349-15357. [CrossRef]

32. Manoun, B.; Azdouz, M.; Azrour, M.; Essehli, R.; Benmokhtar, S.; El Ammari, L.; Ezzahi, A.; Ider, A.; Lazor, P. Synthesis, Rietveld refinements and Raman spectroscopic studies of tricationic lacunar apatites $\mathrm{Na}_{1-\mathrm{x}} \mathrm{K}_{\mathrm{x}} \mathrm{Pb}_{4}\left(\mathrm{AsO}_{4}\right)_{3}(0<\mathrm{x}<1)$. J. Mol. Struct. 2011, 986, 1-9.

33. Van Pevenage, J.; Lauwers, D.; Herremans, D.; Verhaeven, E.; Vekemans, B.; De Clercq, W.; Vincze, L.; Moens, L.; Vandenabeele, P. A combined spectroscopic study on Chinese porcelain containing ruan-cai colours. Anal. Methods 2014, 6, 387-394. [CrossRef]

34. Colomban, P.; Maggetti, M.; d'Albis, A. Non-invasive Raman identification of crystalline and glassy phases in a 1781 Sèvres Royal Factory soft paste porcelain plate. J. Eur. Ceram. Soc. 2018, 38, 5228-5233. [CrossRef]

35. Kissin, S.A. Five element (Ni-Co-As-Ag-Bi) veins. Geosci. Can. 1992, 19, 113-124.

36. Colomban, P. Rocks as blue, green and black pigments/dyes of glazed pottery and enamelled glass artefacts-A review. Eur. J. Mineral. 2014, 25, 863-879. [CrossRef]

37. Berrie, B.H. Mining for Color: New Blues, Yellows, and Translucent Paint. Early Sci. Med. 2015, 20, 308-334. [CrossRef]

38. Pradell, T.; Molina, G.; Molera, J.; Pla, J.; Labrador, A. The use of micro-XRD for the study of glaze color decorations. Appl. Phys. A 2013, 111, 121-127. [CrossRef]

39. Viti, C.; Borgia, I.; Brunetti, B.; Sgamellotti, A.; Mellini, M. Microtexture and microchernistry of glaze and pigments in Italian Renaissance pottery from Gubbio and Deruta. J. Cult. Herit. 2003, 4, 199-210. [CrossRef]

40. Pérez-Arantegui, J.; Resano, M.; Garcia-Ruiz, E.; Vanhaecke, F.; Roldan, C.; Ferrero, J.; Coll, J. Characterization of cobalt pigments found in traditional Valencian ceramics by means of laser ablation-inductively coupled 
plasma mass spectrometry and portable X-ray fluorescence spectrometry. Talanta 2008, 74, 1271-1280. [CrossRef] [PubMed]

41. Pérez-Arantegui, J.; Montull, B.; Resano, M.; Ortega, J.M. Materials and technological evolution of ancient cobalt-blue-decorated ceramics: Pigments and work patterns in tin-glazed objects from Aragon (Spain) from the 15th to the 18th century AD. J. Eur. Ceram. Soc. 2009, 29, 2499-2509. [CrossRef]

42. Colomban, P.; Sagon, G.; Huy, L.Q.; Liem, N.Q.; Mazerolles, L. Vietnamese (15th century) blue-and-white, tam thai and "luster" porcelains/stoneware: Glaze composition and decoration techniques. Archaeometry 2004, 46, 125-136. [CrossRef]

43. Figueiredo, M.O.; Silva, T.P.; Veiga, J.P. A XANES study of cobalt speciation state in blue-and-white glazes from 16th to 17th century Chinese porcelains. J. Electr. Spectrosc. Relat. Phenom. 2012, 185, 97-102. [CrossRef]

44. Dias, M.I.; Prudêncio, M.I.; de Matos, M.A.P.; Rodrigues, A.L. Tracing the origin of blue and white Chinese Porcelain ordered for the Portugese market during the Ming dynasty using INAA. J. Archaeol. Sci. 2013, 40, 3046-3057. [CrossRef]

45. Simsek, G.; Colomban, P.; Wong, S.; Zhao, B.; Rougeulle, A.; Liem, N.Q. Toward a fast non-destructive identification of pottery: The sourcing of 14th-16th century Vietnamese and Chinese ceramic shards. J. Cult. Herit. 2015, 16, 159-172. [CrossRef]

46. Fischer, C.; Hsieh, E. Export Chinese Blue-and-white porcelain: Compositional analysis and sourcing using non-invasive portable XRF and reflectance spectroscopy. J. Archaeol. Sci. 2016, 80, 14-26. [CrossRef]

47. Sandalinas, C.; Ruiz-Moreno, S. Lead-tin-antimony yellow-Historical manufacture, molecular characterization and identification in seventeenth-century Italian paintings. Stud. Conserv. 2004, 49, 41-52. [CrossRef]

48. Sandalinas, C.; Ruiz-Moreno, S.; Lopez-Gil, A.; Miralles, J. Experimental confirmation by Raman spectroscopy of a Pb-Sn-Sb triple oxide yellow pigment in sixteenth-century Italian pottery. J. Raman Spectrosc. 2006, 37, 1146-1153. [CrossRef]

49. Pereira, M.; de Lacerda-Aroso, T.; Gomes, M.J.M.; Mata, A.; Alves, L.C.; Colomban, P. Ancient Portuguese ceramic wall tiles (Azulejos): Characterization of the glaze and ceramic pigments. J. Nano Res. 2009, 8, 79-88. [CrossRef]

50. Rosi, F.; Manuali, V.; Miliani, C.; Brunetti, B.G.; Sgamellotti, A.; Grygar, T.; Hradil, D. Raman scattering features of lead pyroantimonate compounds. Part I: XRD and Raman characterization of $\mathrm{Pb}_{2} \mathrm{Sb}_{2} \mathrm{O}_{7}$ doped with tin and zinc. J. Raman Spectrosc. 2009, 40, 107-111. [CrossRef]

51. Pelosi, C.; Agresti, G.; Santamaria, U.; Mattei, E. Artificial yellow pigments: Production and characterization through spectroscopic methods of analysis. E-Preserv. Sci. 2010, 7, 108-115.

52. Kirmizi, B.; Colomban, P.; Blanc, M. On-site Analysis of Limoges enamels from 16th to 19th centuries. J. Raman Spectrosc. 2010, 41, 1240-1247. [CrossRef]

53. Dik, J.E.; Hermens, R.; Peschar, H. Schenk, Early production recipes for lead antimonite yellow in Italian art. Archaeometry 2005, 47, 593-607. [CrossRef]

54. Dik, J. Scientific analysis of historical paint and the implications for art history and art conservation. The case studies of naples yellow and discoloured smalt. Doctorate Thesis, University of Amsterdam, Amsterdam, The Netherlands, 2003. Available online: https://dare.uva.nl/search?identifier=98d80b7d-a63e-450b-a984611a3d0c0cfe (accessed on 14 August 2020).

55. Bell, I.M.; Clark, R.J.H.; Gibbs, P.J. Raman spectroscopic library of natural an synthetic pigments (pre- 1850 AD). Spectrochim. Acta Part A 1997, 53, 2159-2179. [CrossRef]

56. Colomban, P. The destructive/non-destructive identification of enamelled pottery and glass artifacts and associated pigments-A brief overview. Arts 2013, 2, 77-110. [CrossRef]

57. Neri, E.; Morvan, C.; Colomban, P.; Guerra, M.P. Prigent, Late Roman and Byzantine Mosaic opaque Glass-ceramics Tesserae (5th-9th century). Ceram. Int. 2016, 42, 18859-18869. [CrossRef]

58. Rosi, F.; Manueli, V.; Grygar, T.; Bezdicka, P.; Brunetti, B.G.; Sgamelotti, A.; Burgio, L.; Seccaronif, C.; Miliani, C. Raman scattering features of lead pyroantimonate compounds: Implication for the non-invasive identification of yellow pigments on ancient ceramics. Part II. In situ characterisation of Renaissance plates by portable micro-Raman and XRF studies. J. Raman Spectrosc. 2011, 42, 407-414. [CrossRef]

59. Cartechini, L.; Rosi, F.; Miliani, C.; D’Acapito, F.; Brunetti, B.G.; Sgamellotti, A. Modified Naples yellow in Renaissance majolica: Study of $\mathrm{Pb}-\mathrm{Sb}-\mathrm{Zn}$ and $\mathrm{Pb}$-Sb-Fe ternary pyroantimonates by X-ray absorption spectroscopy. J. Anal. Atom. Spectrom. 2011, 26, 2500-2507. [CrossRef] 
60. Biron, I.; Chopinet, M.-H. Colouring, Decolouring and Opacifying Glass. In Modern Methods for Analysing. Archaeological and Historical Glass, 1st ed.; Janssens, K., Ed.; John Wiley \& Sons Ltd.: London, UK, 2012; pp. 49-66.

61. Verita, M.; Maggetti, M.; Sagui, L.; Santopadre, P. Colors of Roman Glass: An Investigation of the Yellow Sectilia in the Gorga Collection. J. Glass Stud. 2013, 55, 21-34.

62. Froment, F.; Tournié, A.; Colomban, P. Raman identification of natural red to yellow pigments: Ochre and iron-containing ores. J. Raman Spectrosc. 2008, 39, 560-568. [CrossRef]

63. Owens, F.J.; Orosz, J. Effect of nanosizing on lattice and magnon modes of hematite. Solid State Commun. 2006, 138, 95-98. [CrossRef]

64. Hunt, L.B. The true story of Purple of Cassius. Gold Bull. 1976, 9, 134-139. [CrossRef]

65. Colomban, P. The Use of Metal Nanoparticles to Produce Yellow, Red and Iridescent Colour, from Bronze Age to Present Times in Lustre Pottery and Glass: Solid State Chemistry, Spectroscopy and Nanostructure. J. Nano Res. 2009, 8, 109-132. [CrossRef]

66. Geyssant, J. Secret du verre rouge transparent de Bernard Perrot et comparaison avec celui de Johann Kunckel. In Bernard Perrot (1640-1709): Secrets et Chefs-d'œuvre des Verreries Royales d'Orléans, Catalogue; Musée des Beaux-Arts d'Orléans, SOMOGY Editions d'Arts: Paris, France, 2010; pp. 51-54.

67. Louis, C. Gold nanoparticles in the past: Before the Nanotechnology Era. In Gold Nanoparticles for Physics, Chemistry and Biology; Louis, C., Pluchery, O., Eds.; Imperial College Press: London, UK, 2012; pp. 1-27.

68. Colomban, P. Polymerisation Degree and Raman Identification of Ancient Glasses used for Jewellery, Ceramics Enamels and Mosaics. J. Non-Cryst. Solids 2003, 323, 180-187. [CrossRef]

69. Colomban, P.; Tournié, A.; Bellot-Gurlet, L. Raman Identification of glassy silicates used in ceramic, glass and jewellry: A tentative differentiation guide. J. Raman Spectrosc. 2006, 37, 841-852. [CrossRef]

70. Colomban, P.; Paulsen, O. Non-destructive Raman Determination of the Structure and Composition of Glazes by Raman Spectroscopy. J. Am. Ceram. Soc. 2005, 88, 390-395. [CrossRef]

71. Colomban, P. Non-Destructive Raman Analysis of Ancient Glasses and Glazes, in Modern Methods for Analysing Archaeological and Historical Glass, 1st ed.; Janssens, K., Ed.; John Wiley \& Sons Ltd.: London, UK, 2012; pp. 275-300.

72. Labet, V.; Colomban, P. Vibrational properties of silicates: A cluster model able to reproduce the effect of " $\mathrm{SiO}_{4}$ " polymerization on Raman intensities. J. Non-Cryst. Solids 2013, 370, 10-17. [CrossRef]

73. Su, Y.; Qu, L.; Duan, H.; Tarcea, N.; Shen, A.; Popp, J.; Hu, J. Elemental analysis-aided Raman spectroscopic studies on Chinese cloisonné wares and painted enamels from the Imperial palace. Spectrochim. Acta A-Mol. Biomol. Spectrosc. 2016, 153, 165-170. [CrossRef] [PubMed]

74. Henderson, J.; Tregear, M.; Wood, N. The technology of sixteenth- and seventeenth century Chinese Cloisonné enamels. Archaeometry 1989, 31, 133-146. [CrossRef]

75. Shih, C.F. Radiant Luminance: The Painted Enamelware of the Qing Imperial Court; The National Palace Museum of Taipei: Taipei, Taiwan, 2012.

76. Wood, N. Chinese Glazes: Their Origins, Chemistry and Recreation; A \& C Black: London, UK, 1999.

77. Shi, N.C. Analyse Scientifique des Couleurs Falang D’objets Conservés au Palais ou Retrouvés en Contexte Archéologique. In Proceedings of the French-Chinese Meeting on Enamelling Technology, Collège de France, Paris, France, 10 September 2019.

(C) 2020 by the authors. Licensee MDPI, Basel, Switzerland. This article is an open access article distributed under the terms and conditions of the Creative Commons Attribution (CC BY) license (http://creativecommons.org/licenses/by/4.0/). 